\title{
Health Cost Estimation of Traffic-Related Air Pollution and Assessing the Pollution Reduction Potential of Zero-Emission Vehicles in Toronto, Canada
}

\author{
Hamidreza Shamsi ${ }^{1}$ (D), Mohammad Munshed ${ }^{1}$, Manh-Kien Tran ${ }^{2}\left(\mathbb{D}\right.$, Youngwoo Lee ${ }^{2}$, Sean Walker $^{3}$, Jesse The ${ }^{1}$, \\ Kaamran Raahemifar ${ }^{4}$ and Michael Fowler $2, * \mathbb{D}$ \\ 1 Department of Mechanical and Mechatronics Engineering, University of Waterloo, Waterloo, ON N2L 3G1, \\ Canada; hshamsi@uwaterloo.ca (H.S.); mmunshed@uwaterloo.ca (M.M.); jthe@uwaterloo.ca (J.T.) \\ 2 Department of Chemical Engineering, University of Waterloo, Waterloo, ON N2L 3G1, Canada; \\ kmtran@uwaterloo.ca (M.-K.T.); youngwoo.lee@uwaterloo.ca (Y.L.) \\ 3 Department of Chemical and Biomolecular Engineering, University of South Alabama, Mobile, AL 36688, \\ USA; seanwalker@southalabama.edu \\ 4 College of Information Sciences and Technology (IST), Pennsylvania State University, State College, PA 16801, \\ USA; kraahemifar@uwaterloo.ca \\ * Correspondence: mfowler@uwaterloo.ca; Tel.: +1-519-888-4567 (ext. 33415)
}

\section{check for} updates

Citation: Shamsi, H.; Munshed, M.; Tran, M.-K.; Lee, Y.; Walker, S.; The, J.; Raahemifar, K.; Fowler, M. Health Cost Estimation of Traffic-Related Air Pollution and Assessing the Pollution Reduction Potential of Zero-Emission Vehicles in Toronto, Canada. Energies 2021, 14, 4956. https://doi.org/ 10.3390/en14164956

Academic Editors: Umberto Desideri and Sergio Ulgiati

Received: 20 May 2021

Accepted: 10 August 2021

Published: 12 August 2021

Publisher's Note: MDPI stays neutral with regard to jurisdictional claims in published maps and institutional affiliations.

Copyright: (c) 2021 by the authors. Licensee MDPI, Basel, Switzerland. This article is an open access article distributed under the terms and conditions of the Creative Commons Attribution (CC BY) license (https:/ / creativecommons.org/licenses/by/ $4.0 /)$.
Abstract: Fossil fuel vehicles, emitting air toxics into the atmosphere, impose a heavy burden on the economy through additional health care expenses and ecological degradation. Air pollution is responsible for millions of deaths and chronic and acute health problems every year, such as asthma and chronic obstructive pulmonary disease. The fossil-fuel-based transportation system releases tons of toxic gases into the atmosphere putting human health at risk, especially in urban areas. This analysis aims to determine the economic burden of environmental and health impacts caused by Highway 401 traffic. Due to the high volume of vehicles driving on the Toronto Highway 401 corridor, there is an annual release of 3771 tonnes of carbon dioxide equivalent $\left(\mathrm{CO}_{2} \mathrm{e}\right)$. These emissions are mainly emitted onsite through the combustion of gasoline and diesel fuel. The integration of electric and hydrogen vehicles shows maximum reductions of $405-476 \mathrm{~g} \mathrm{CO}_{2} \mathrm{e}$ per vehicle-kilometer. Besides these carbon dioxide emissions, there is also a large amount of hazardous air pollutants. To examine the impact of air pollution on human health, the mass and concentrations of criteria pollutants of $\mathrm{PM}_{2.5}$ and $\mathrm{NO}_{\mathrm{x}}$ emitted by passenger vehicles and commercial trucks on Highway 401 were determined using the MOVES2014b software. Then, an air dispersion model (AERMOD) was used to find the concentration of different pollutants at the receptor's location. The increased risk of health issues was calculated using hazard ratios from literature. Finally, the health cost of air pollution from Highway 401 traffic was estimated to be CAD 416 million per year using the value of statistical life, which is significantly higher than the climate change costs of CAD 55 million per year due to air pollution.

Keywords: health cost analysis; air pollution cost analysis; air pollution modeling; life cycle analysis; zero-emission vehicles

\section{Introduction}

Despite Canada having some of the cleanest air globally and ranking amongst the lowest levels of pollution emissions in fine particulate matter $\left(\mathrm{PM}_{2.5}\right)$ concentrations, Health Canada found that approximately 14,600 Canadians died prematurely due to air pollution in 2015 [1]. The trends show that the amount of $\mathrm{PM}_{2.5}$ being emitted in Canada is on the rise. The number of Canadians succumbing to poor air quality continues to rise while the air quality is worsening. Action to reduce the amount of pollution in the most affected areas must be taken to prevent the unnecessary loss of life. The air quality is worst in highly populated urban areas, such as the Greater Toronto Area (GTA) [2]. This decrease in 
air quality can be attributed to fossil-fuel-powered Internal Combustion Engine Vehicles (ICEV) [3]. These ICEVs cause the increased concentration of harmful products in the air, including $\mathrm{CO}, \mathrm{O}_{3}, \mathrm{NO}_{2}$, and $\mathrm{PM}_{2.5}$ which are known to cause acute and chronic medical problems such as asthma, bronchiolitis, and also lung cancer [4]. However, the penetration of zero-emission vehicles (ZEVs) into Canada's traffic mix can alleviate this problem by eliminating these harmful exhaust products [5]. This paper presents an assessment of the impacts of electric passenger vehicles and hydrogen fuel-cell trucks on human health and greenhouse gas (GHG) emissions in the Toronto 401 corridor.

To determine the total impact on GHG emissions of switching from diesel to hydrogen for semi-trucks and gasoline to electric and hydrogen for passenger cars in Ontario, a wellto-wheels (WTW) life cycle assessment (LCA), as shown in Figure 1, is considered. LCA methodology employs a cradle-to-grave approach to assess the environmental impact of a product or service over its life cycle. The processing activity entails the following: extraction of raw materials, manufacturing, transportation, recycling, and final disposal. In automotive LCA, vehicle production and vehicle end-of-life are disregarded due to the high level of uniformity in these processes across fuel types.

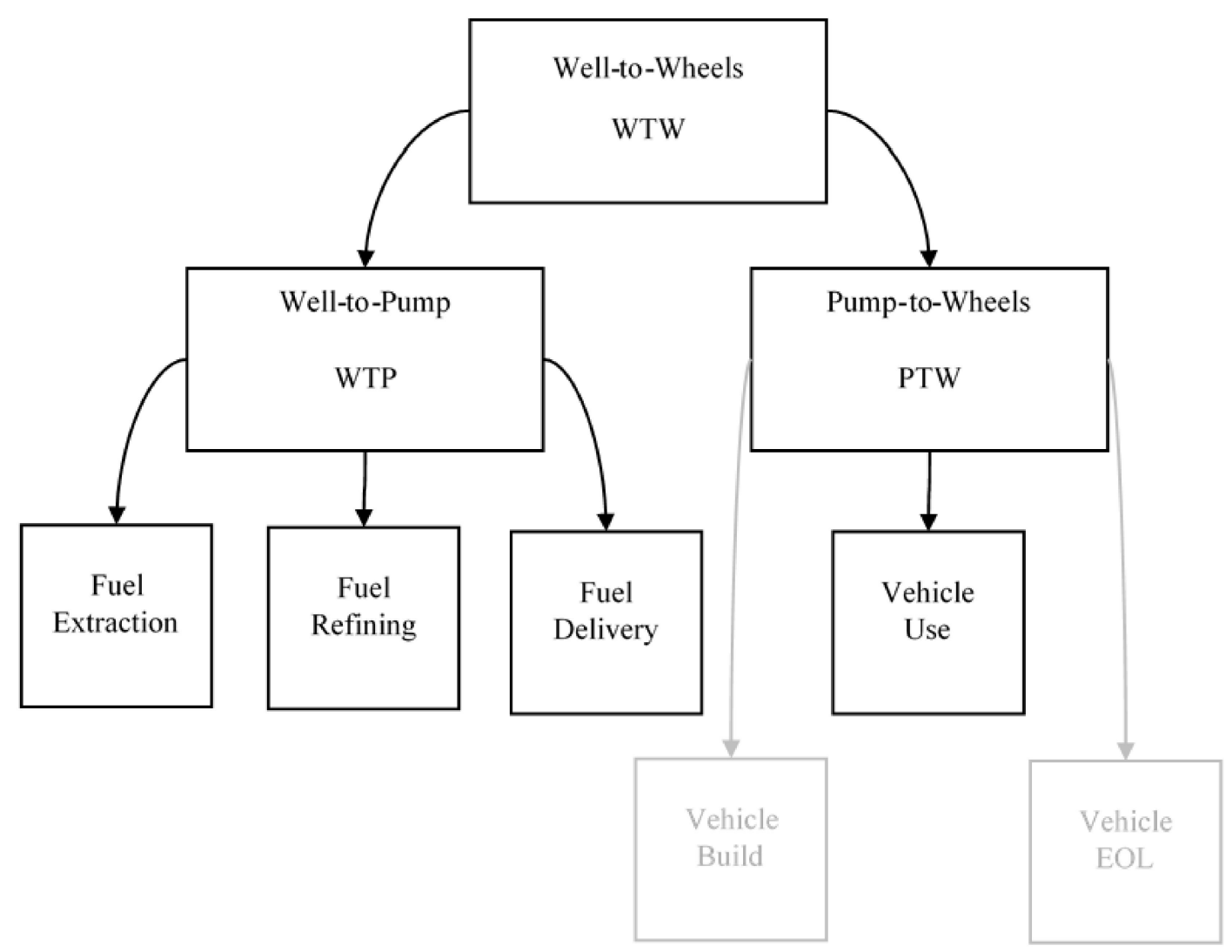

Figure 1. Well-to-Wheels LCA Method Employed in Comparison of Diesel and HFCV Semi-Trucks. (Due to similarity across fuel types, the Vehicle Build and Vehicle EOL are omitted).

In addition to the GHG impacts of internal combustion engines, air pollution is a problem that significantly impacts human health. The exhaust emissions from gasoline and diesel vehicles lead to a significant increase in wheezing, coughing, and cases of lung diseases like asthma [6]. There is a substantial increase in the concentration of air pollutants within proximity to US highways, including $\mathrm{CO}, \mathrm{NO}_{2}, \mathrm{SO}_{2}, \mathrm{PM}$, and black carbon (BC) [7]. These pollutants increase the risk of cardiopulmonary mortality in adults and decrease lung function in children between 4 and 8 years of age for those living within $300 \mathrm{~m}$ of the highway. Higher exposure to $\mathrm{NO}_{2}, \mathrm{NO}$, and $\mathrm{CO}$ is correlated with a higher prevalence of childhood asthma [8]. Further, poor air quality has been strongly linked with poor overall 
living conditions [9]. Fine particulate air pollution is found to cause 0.8 million deaths, and 6.4 million lost life-years globally per year [10].

In Canada, the risk of human health impacts from air pollution is continually increasing. When samples were collected to predict $\mathrm{PM}_{2.5}$ and ozone levels in the city of Toronto, along with health data of 2360 subjects, it was found that there was a $17 \%$ increase in mortality and a $40 \%$ increase in circulatory-related mortality when exposed to $4 \mathrm{ppb}$ $\mathrm{NO}_{2}$ or higher [11]. Further research has examined the relationship between premature mortality and harmful air pollutants across 11 Canadian cities [12]. The findings show that $\mathrm{NO}_{2}$ increased the risk of mortality by $4.1 \%$, followed by ozone $(1.8 \%), \mathrm{SO}_{2}(1.4 \%)$, and $\mathrm{CO}$ $(0.9 \%)$. A similar study was conducted by collecting samples of air pollutants over a 16-year period in ten Canadian cities, which also found that $\mathrm{NO}_{2}$ had the strongest association with mortality [13]. A complex relationship exists between the increasing incidence of congestive heart failure and exposure to air pollutants across Canada [14]. Health Canada concluded that in 2019, there was a total of 9700 premature deaths due to $\mathrm{PM}_{2.5}$ chronic exposure, 940 deaths due to $\mathrm{NO}_{2}$ acute exposure, 2700 deaths due to $\mathrm{O}_{3}$ acute exposure, and 1300 deaths due to $\mathrm{O}_{3}$ chronic exposure in Canada [1]. Canadians are at an increased risk of health problems due to air pollution. To regulate airborne pollutants and mitigate this risk, the province of Ontario publishes a list of acceptable airborne concentrations of pollutants. On this list, primary pollutants related to the operation of motor vehicles include $\mathrm{CO}, \mathrm{NO}_{2}, \mathrm{SO}_{2}$, and $\mathrm{PM}$.

A spike in $\mathrm{SO}_{2}, \mathrm{NO}_{2}$, and $\mathrm{NH}_{3}$ pollution, which started in the 1950s and peaked in the 1980s, caused a significant increase in acid rain cases [15]. Due to public opposition to the increasing $\mathrm{SO}_{2}$ emissions globally, acid rain has been drastically reduced. In Canada, for example, there was an $80 \%$ decrease in $\mathrm{SO}_{2}$ emissions between 1980 and 2015. A spatial analysis between socioeconomic groups and air pollution within three large Canadian cities-Toronto, Vancouver, and Montreal—found that areas with a larger proportion of residents generally had greater exposure to ambient $\mathrm{NO}_{2}$ pollution [16]. Additionally, there is an association between greater $\mathrm{NO}_{2}$ exposure and signs of social deprivation. Another article investigated the change in air quality due to the increasing albedo effect in Montreal. The authors increased the reflectivity of roofs, walls, and roads to decrease the urban heat island (UHI) effect, reducing the overall surface temperature [17]. This temperature increase resulted in a $3 \%$ decrease in the 8 -h averaged $\mathrm{O}_{3}$ concentration and a reduction of $1.8 \mu \mathrm{g} / \mathrm{m}^{3}$ in the 24-h averaged $\mathrm{PM}_{2.5}$ concentration [17]. Air quality data collected during the COVID-19 lockdown in Ontario showed no change in PM. However, the average $\mathrm{O}_{3}$, $\mathrm{NO}_{2}$, and $\mathrm{NO}$ concentrations were lower than in previous years [18]. It should be noted that during the lockdown in Ontario, there were still many human activities going on in terms of transportation. However, with slightly fewer transportation activities, less pollution was observed, and hence it is evident that air pollutants could be reduced significantly with a lower level of transportation emissions.

Because of the impact of air pollutants on human health, countries are burdened with increasing health costs caused by air pollution. In 1991, the total health costs of pollution from motor vehicles totaled between USD 54.7 billion and USD 672.3 billion [19]. The gross annual damage wrought by air pollution on the US economy in 2002, determined by summing all the public health costs from air pollution, was between USD 71 billion and USD 277 billion [20]. Chronic exposure to $\mathrm{PM}_{2.5}$ was found to be the most considerable health burden in 25 European cities, with a calculated yearly monetary gain of around USD 37 billion if the air pollution is reduced to the World Health Organization (WHO) guidelines. The cost of $\mathrm{PM}_{2.5}$ air pollution in the city of Skopje was estimated to be between $€ 570$ million and $€ 1470$ million in 2012 [21]. Researchers experimented across thirty provinces in China to assess the economic health benefit of decreasing air pollution. The results stated that the total loss resulting from air pollution totaled an estimated $¥ 346.26$ billion, or USD 53 billion, in 2007 [22]. In addition, a similar study focused on the populated urban areas of China found that in 2013, the total health cost caused by air pollution was USD 14.8 to USD 25.3 billion [23]. 
The public health costs of air pollution in Canada are also high. Analysis of agricultural air pollution in Canada found that 1480 lives could be saved annually by a $50 \%$ reduction in agriculture-related air pollution [24]. The economic value of such a reduction in air pollution is estimated between USD 1.66 and USD 9.4 billion [24]. The air pollution removed by urban trees in Canada has both economic and health benefits. In 86 Canadian cities, urban trees removed between 7500 and 21,100 tonnes of air pollution in 2010, resulting in an annual saving of CAD 52.5-402.6 million [25]. Multiple studies have shown that transportation is one of the primary sources of air pollutions and can lead to significant health costs $[5-8,19,26]$. Examining the impact of vehicle mix on air pollution, having even $1 \%$ of the heavy-duty vehicle fleet in Ontario be zero-emission vehicles has an environmental and health benefit valued at USD 1.63 million per year [5]. The contribution of commercial diesel vehicles to the air quality in the GTA and Hamilton was estimated to be $6-22 \%$ for $\mathrm{NO}_{2}$ and $\mathrm{BC}$, and $3 \%$ for $\mathrm{PM}_{2.5}$ and $\mathrm{O}_{3}$ [26]. The combined emissions of all commercial vehicles were calculated to have a total health impact of 9810 Years of Life Lost (YLL), corresponding to CAD 3.2 billion.

With the emergence of power-to-gas (P2G) technology and infrastructure, the possibility of gradually replacing conventional vehicles with hydrogen fuel cell (FC) vehicles has become more achievable. P2G is a method of storing and transporting energy through hydrogen production from renewable and conventional sources. Using P2G, the surplus energy produced from renewable sources can be used to produce hydrogen, which is then stored and used to produce electricity, renewable natural gas, and in other hydrogen applications such as hydrogen FC vehicles. The introduction of more hydrogen FC vehicles, in addition to battery electric vehicles, can potentially improve the air quality and ultimately the living quality in Canada, resulting in various environmental, economic, and health benefits. In this paper, the costs of the adverse health effects from air pollution and the estimation of the potential monetary benefit that ZEVs will provide in reducing these health costs are determined and compared with the costs of climate change. The study uses the case study of Highway 401 in Ontario within the City of Toronto, one of the busiest highways in North America, as the basis for calculations. The case studies and results found in this paper can also give a general idea about the benefits of ZEVs in other highways and other countries. The authors use an emission model, an air dispersing model, and a health risk model to find the health costs of traffic-related air pollution near the studied highway. The health and environmental benefits of ZEVs, including FC trucks and electric passenger vehicles, are calculated in different scenarios based on the integrated health cost calculation model and the life-cycle emission model. The results from this paper show the significant health and environmental effects of traffic-related air pollution on people who are living in the vicinity of major highways in Canada, and to a certain extent, in the vicinity of other major highways in the world, as well as providing a potential solution by showing the benefits of a mass roll-out of ZEVs.

\section{Methodology}

\subsection{Climate Change Cost Calculation}

The cost of climate change is estimated using an estimated price of GHGs per tonne of carbon dioxide equivalents $\left(\mathrm{CO}_{2} \mathrm{e}\right)$. The value of carbon has been estimated to be only USD 2 per tonne globally, while a higher estimated value of USD 75 per tonne is necessary to entice corporations and individuals into reducing GHG emissions [27]. In this analysis, a value of CAD 40 per tonne of $\mathrm{CO}_{2}$, which is the value of the Canadian carbon tax as of April 2021, is used [28].

\subsection{Health Cost Modeling and Calculation}

Figure 2 shows the schematic of the integrated models for health cost calculation. A four-step model was built to find the traffic-related health cost of Highway 401. The first step was finding the amount of pollution coming out of diesel trucks in different sections of Highway 401. Next, an air dispersion model was used to find the concentrations of 
different pollutants caused by light vehicles and trucks moving along Highway 401 . The third step was to investigate the health impacts of air pollution on residents living in the vicinity of Highway 401. Finally, in the fourth step, the increased risk of mortality was converted into dollar values. The four steps are described in the following subsections.

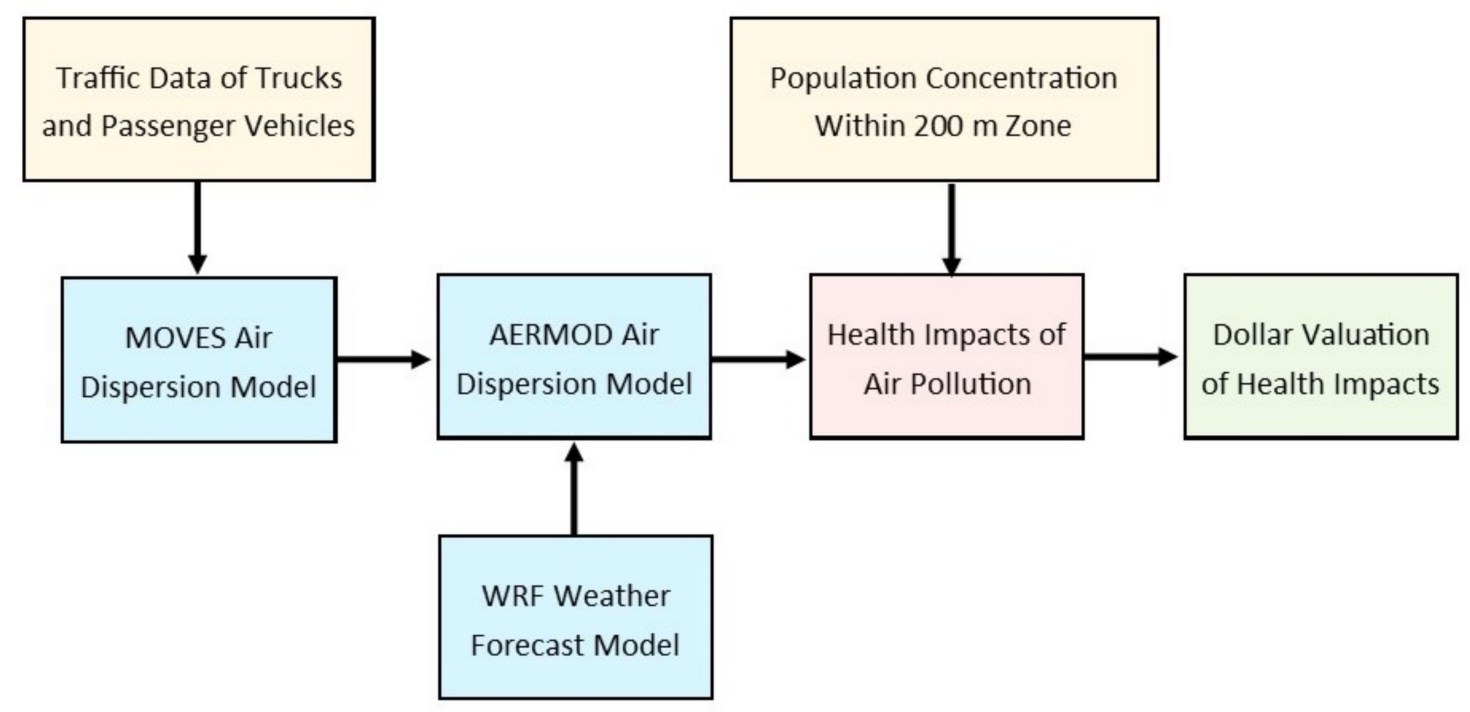

Figure 2. Schematic of the health cost calculation model.

\subsubsection{Total Emissions from Highway 401}

To find the total air pollution emissions from diesel trucks traveling along Highway 401, EPA's Motor Vehicle Emission Simulator (MOVES2014b) is used [29] to estimate the pollution emitted from traffic on Highway 401. MOVES2014b is a Windows-based model designed to provide an accurate estimation of emissions from motor vehicles. The model performs a series of calculations based on vehicle types, geographic areas, time of the year, road type, and other factors to estimate bulk emissions or emission rates.

The Annual Average Daily Traffic (AADT) data from 2016 was found from Ontario's Ministry of Transportation traffic repository [30]. AADT, seasonal traffic change factor, and hourly traffic change factor were inputted into the MOVES2014b software to find the total emissions of passenger vehicles and trucks along Highway 401. Figure 3 shows the AADT along Highway 401, where the $\mathrm{x}$-axis is the distance from the western end of Highway 401 in Toronto. As shown in Figure 3, more vehicles pass in the west part of Highway 401 in Toronto. Therefore, it is expected that the corridor-related pollution concentration is higher in the western regions. The numbers in Figure 3, taken from [30], include class 7, 8, 9, and 10 trucks, which are heavy-duty truck classes. 


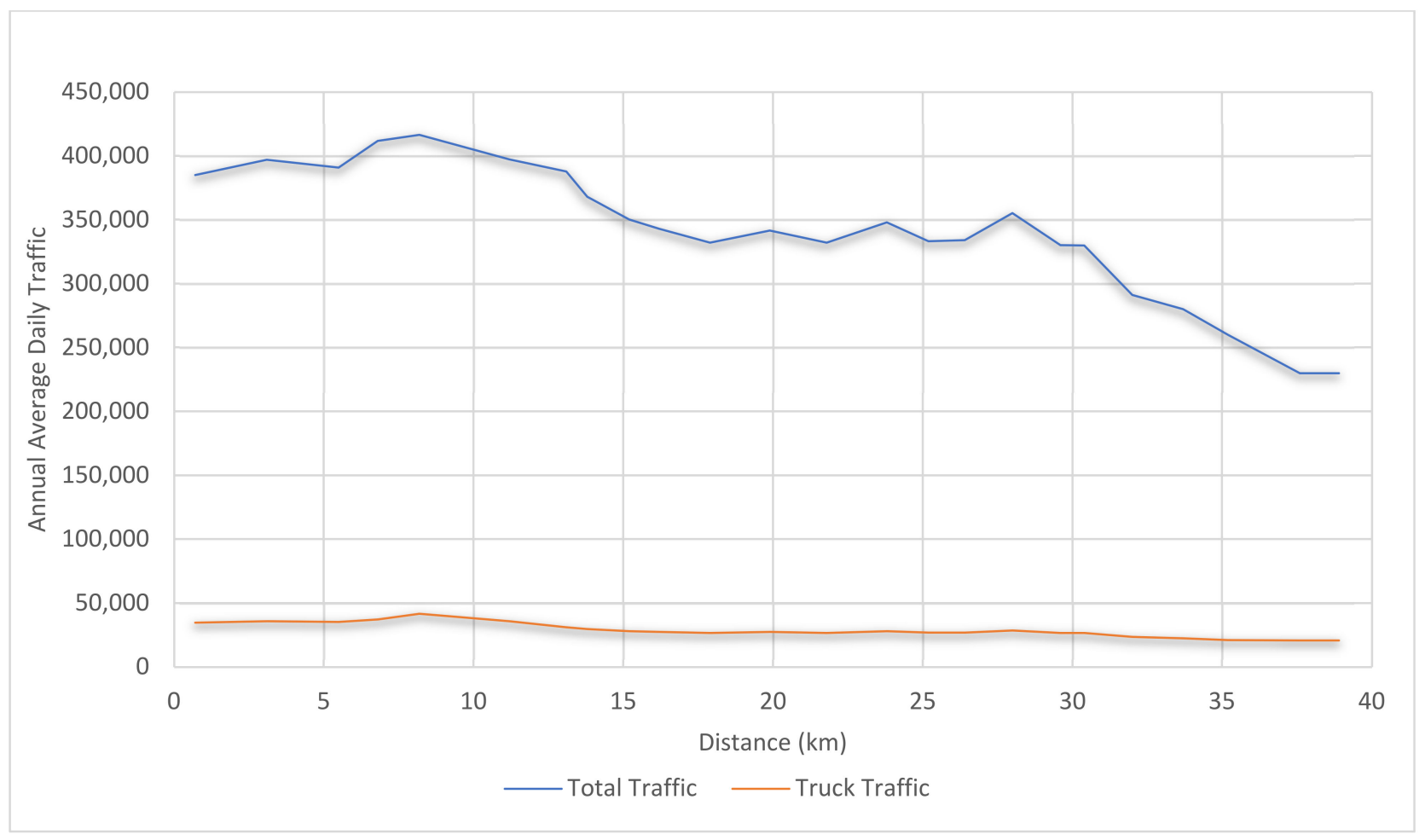

Figure 3. Annual average daily traffic (AADT) along Highway 401.

Figure 4 shows the seasonal-hourly traffic factor. Fall and winter have higher traffic factors. Also, we can see that the PM peak in all seasons is the busiest period in Highway 401. Also, overnight, traffic volume drops, which can result in a drop in air pollution.

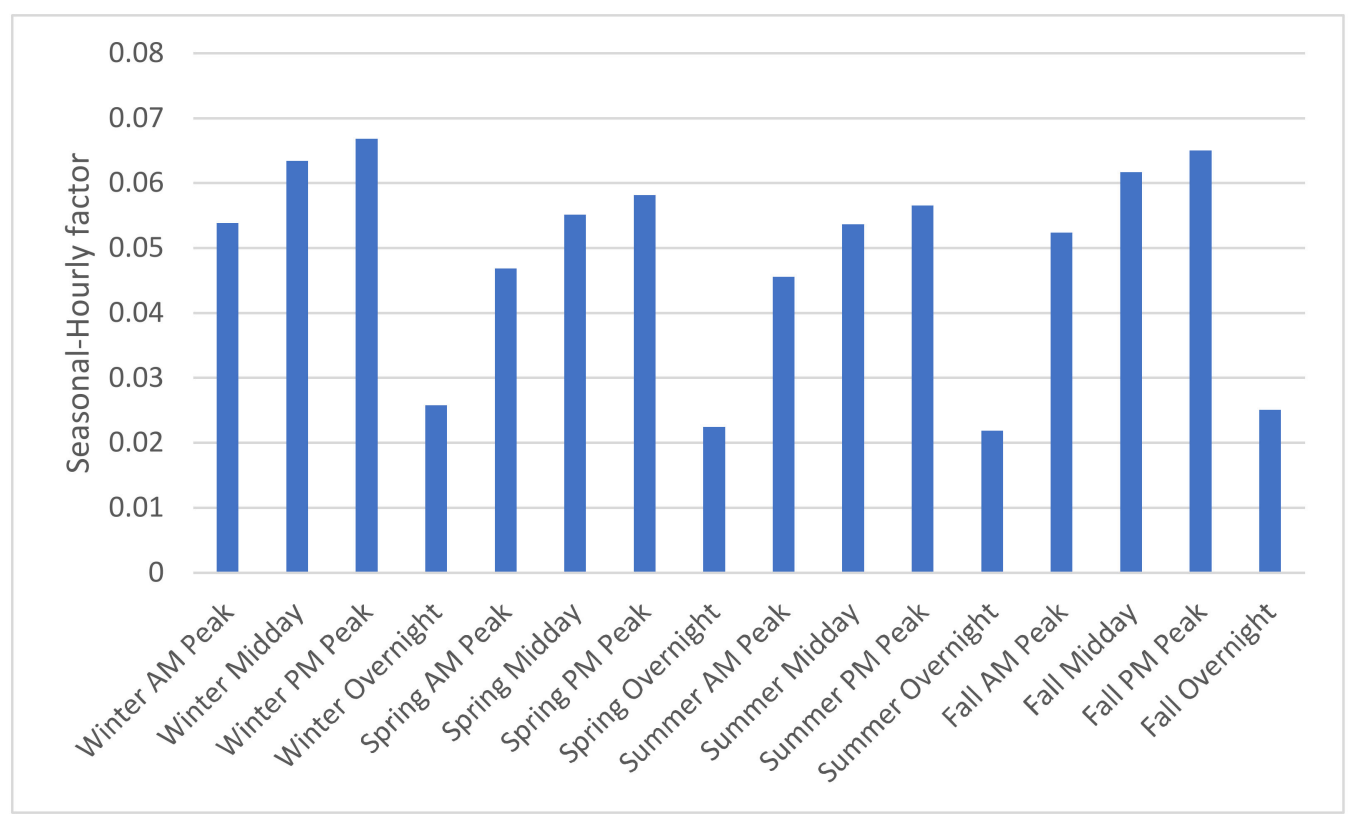

Figure 4. Traffic seasonal-hourly adjustment factors.

\subsubsection{Dispersion of Air Pollutants along Highway 401}

To find the concentrations of air pollutants in the vicinity of Highway 401, the emission data from the first step as an input to EPA's AERMOD executable version 19191 was used [31]. AERMOD is a steady-state Gaussian plume air dispersion model and is the 
U.S. EPA preferred dispersion model for near-field impacts (less than $50 \mathrm{~km}$ ). The model can handle flat or elevated terrain. Dispersion is conducted as a plume from each source which disperses entirely in the downwind direction. The meteorological preprocessor for AERMOD called AERMET calculates hourly values of advanced turbulence parameters (e.g., sensible heat flux, convective velocity scale, surface friction velocity, Monin-Obukhov length, etc.). These parameters are used to build the planetary boundary layer for each modeled hour. Table 1 shows the features and inputs of the AERMOD model. Highway 401 in Toronto is divided into 71 line sources, which their emission rates are calculated using MOVES2014b. Also, a network of discrete receptors is generated using TRAQS. The Transportation Air Quality System (TRAQS) is an open-source software interface that successfully integrates regulatory mobile emissions models-MOVES or EMFAC with AERMOD. Spacing between receptors is $100 \mathrm{~m}$. Also, the distance between different layers of receptors is $10 \mathrm{~m}$ in the vicinity of the highway; however, it increases to $5 \mathrm{~km}$ in regions far from the highway.

Table 1. AERMOD inputs.

\begin{tabular}{cc}
\hline Input & Description \\
\hline MODELOPT & FASTALL \\
AVERTIME & Annual \\
POLLUTID & $\mathrm{PM}_{2.5}$ and $\mathrm{NO}_{\mathrm{x}}$ \\
Source type & Line Sources \\
Receptor type & Discrete Cartesian Receptors \\
\hline
\end{tabular}

To generate meteorological data for the AERMOD air dispersion model, the Weather Research and Forecasting (WRF) model was used. WRF is a mesoscale numerical weather prediction system jointly developed by the National Center for Atmospheric Research (NCAR), the National Oceanic and Atmospheric Administration, the U.S. Air Force, and others [32]. The WRF model was used to extract the necessary meteorological data for air dispersion modeling, such as the surface and profile files along Highway 401. The Weather Research \& Forecasting model was executed from 2016 to 2020 at 4-km horizontal grid resolution. The U.S. Environmental Protection Agency's (U.S. EPA) Mesoscale Model Interface Program was used to format output from WRF for use in the AERMOD modeling system. The input data is used from the National Centers for Environmental Prediction (NCEP) Global Forecast System (GFS) 0.5-degree resolution data. The GFS 0.5-deg data is given every $6 \mathrm{~h}$ at $00,06,12$, and 18Z. The input for the sea surface temperature (SST) data comes from the GFS 0.5-degree data, updated daily as each WRF simulation is done for $24 \mathrm{~h}$. Details on the setup used to execute the WRF model (Version 4.0) are provided in Table 2.

Table 2. WRF setup characteristics.

\begin{tabular}{ccc}
\hline Domain & Resolution (km) & Number of Grid Points in X and Y \\
\hline Domain 1 & 27 & $34 \times 34$ \\
\hline Domain 2 & 9 & $34 \times 34$ \\
\hline Domain 3 & 3 & $34 \times 34$ \\
\hline
\end{tabular}

Figure 5 shows a predominant wind blowing from the North-West direction 13\% of the time. The average wind speed for the five years from 2016 to 2020 is $3.32 \mathrm{~m} / \mathrm{s}$ with 489 $\mathrm{h}$ of calm conditions. 


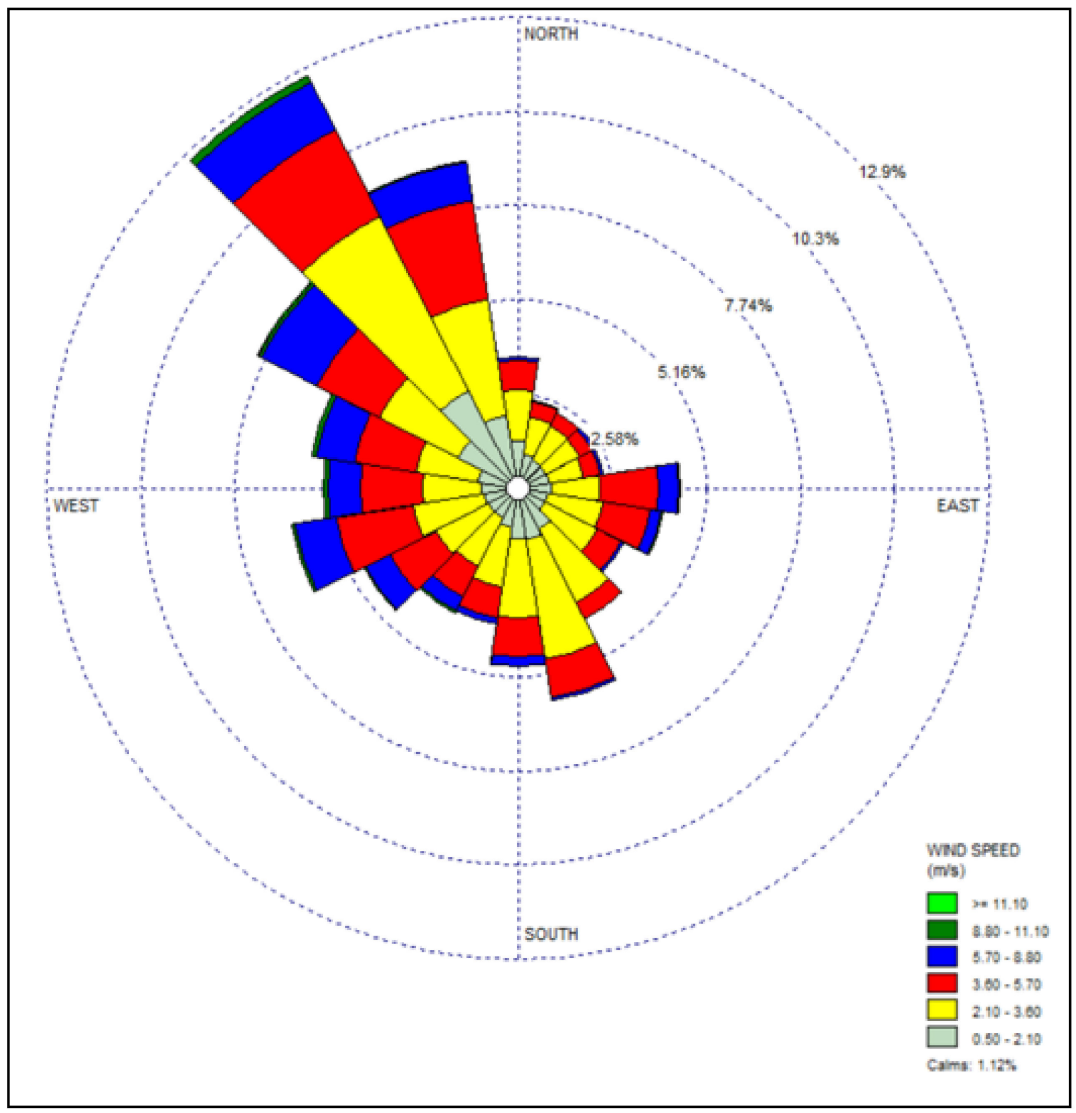

Figure 5. Wind rose diagram at Toronto West Air Monitoring Site.

The metrological data, which is derived from the WRF model, was then inputted into the AERMOD air dispersion model to accurately map the dispersion of various air pollutants along Highway 401. Using the AERMOD air dispersion model, the concentrations of air pollutants were found within 10,000 $\mathrm{m}$ of Highway 401 at different receptors. A receptor is a location with exact coordinates within the air dispersion model where the concentration is calculated.

\subsubsection{Risk Analysis}

Hazard ratios are used to find the increased risk of mortality due to Highway 401 traffic in Toronto [33]. According to [33], mortality increases by 1.04 (95\% CI 1.02-1.06) with a rise of $10 \mu \mathrm{g} / \mathrm{m}^{3}$ in annual $\mathrm{NO}_{2}$ concentration. It is assumed that almost all $\mathrm{NO}_{x}$ becomes $\mathrm{NO}_{2}$ in a few minutes, meaning the health risk of $\mathrm{NO}_{x}$ would be relatively equal to the health risk of $\mathrm{NO}_{2}$. It should be noted that the total conversion of $\mathrm{NO}_{\mathrm{x}}$ to $\mathrm{NO}_{2}$ is a conservative assumption. For calculating the increased risk of mortality, the current mortality rate must be taken into calculation. According to Statistics Canada, the mortality rate per 1000 population was 7.3 in 2017 [34]. Combining population data, mortality rate, and increased risk of mortality due to pollution, one can find the increased number of premature death due to Highway 401 traffic pollution.

\subsubsection{Health Cost Calculation}

To find the health cost of the pollution to the economy in monetary units, the Value of Statistical Life (VSL) metric is used. VSL is the marginal rate of substitution between income and mortality risk was used [35]. According to [36], the mean VSL for Canada is CAD 5.2 million, ranging from a low of CAD 3.1 million to a high of CAD 10.4 million in 1996 CAD. Considering inflation, the mean VSL in 2020 dollars is equal to CAD 8 million. 


\subsection{Scenarios}

Six scenarios are defined to examine the effect of ZEVs on air pollution as well as pollution costs. In this regard, a specific percentage of passenger vehicles is assumed to have become battery electric vehicles in three scenarios. The other three scenarios assumed the substitution of heavy-duty diesel trucks by hydrogen FC trucks. Table 3 demonstrates the shares of vehicles in the six scenarios.

Table 3. Scenario Definition for Cost Calculation.

\begin{tabular}{ccc}
\hline Scenario & \% Electric Passenger Vehicles & \% Fuel Cell Trucks \\
\hline $1-10 \%$ Electric passenger vehicle & 10 & 0 \\
\hline $2-10 \%$ Fuel cell trucks & 0 & 10 \\
\hline $3-50 \%$ Electric passenger vehicle & 50 & 0 \\
\hline $4-50 \%$ Fuel cell trucks & 0 & 50 \\
\hline $5-100 \%$ Electric passenger vehicle & 100 & 0 \\
\hline $6-100 \%$ Fuel cell trucks & 0 & 100 \\
\hline
\end{tabular}

\section{Results}

\subsection{Climate Change Cost}

In this analysis, the pump-to-wheels (PTW) emissions are created onsite as vehicles travel through Highway 401 in Toronto. Looking at the 401 Toronto corridor between Dixon Road and Meadowvale Road, there were 1,097,281 vehicle miles driven by semi-trucks and 7,136,138 vehicle miles driven by passenger cars for a total of 11,913,869 vehicle-mile, as tabulated in Table 4 [30].

Table 4. Vehicle-kilometers driven by heavy-duty trucks and passenger cars on 401 Toronto (2016).

\begin{tabular}{ccc}
\hline Portion & Diesel Heavy-Duty Truck & Gasoline Passenger Vehicle \\
\hline Eastern & 183,144 & $1,999,776$ \\
\hline Central & 384,083 & $4,416,957$ \\
\hline West & 530,054 & $5,497,136$ \\
\hline Total & $1,097,281$ & $11,913,869$ \\
\hline
\end{tabular}

Using the Greenhouse gases, Regulated Emissions, and Energy use in Technologies (GREET) transportation LCA tool, the per kilometer emissions results were determined for diesel trucks and gasoline passenger vehicles, as seen in Table 5. If hydrogen FC semitrucks and electric vehicles are charged using stand-alone solar power, there will be no life-cycle greenhouse gases for either technology [37].

Table 5. Grams of greenhouse gas emissions $\left(\mathrm{CO}_{2} \mathrm{e}\right)$ per vehicle-kilometer for diesel trucks and gasoline automobiles.

\begin{tabular}{ccc}
\hline Phase & Diesel Heavy-Duty Truck & Gasoline Passenger Vehicle \\
\hline Well-to-Pump & 9.8 & 13.5 \\
\hline Pump-to-Wheels & 348.4 & 270.0 \\
\hline Well-to-Wheels & 358.2 & 283.5 \\
\hline
\end{tabular}

Combining the information, it is possible to estimate the total current greenhouse gas emissions from traffic in this section of Toronto. Additionally, it is possible to determine the impacts of different traffic composition mixes on the overall amount of $\mathrm{CO}_{2} \mathrm{e}$. Table 6 shows the total emissions in tonnes of $\mathrm{CO}_{2} \mathrm{e}$, in addition to the total reductions, for six different scenarios. 
Table 6. Thousands of metric tons of $\mathrm{CO}_{2} \mathrm{e}$ produced annually on 401 Toronto under different traffic profiles.

\begin{tabular}{cccc}
\hline \multirow{2}{*}{ Scenario } & Well-to-Pump & Pump-to-Wheels & Well-to-Wheels \\
\cline { 2 - 4 } & 57 & 1196 & 1253 \\
\hline $\begin{array}{c}\text { Scenario } 1 \\
(10 \% \text { EV })\end{array}$ & 62 & 1300 & 1361 \\
\hline $\begin{array}{c}\text { Scenario 2 } \\
(10 \% \text { FC Trucks })\end{array}$ & 33 & 727 & 760 \\
\hline $\begin{array}{c}\text { Scenario 3 } \\
(50 \% \text { EV })\end{array}$ & 61 & 1244 & 1305 \\
\hline $\begin{array}{c}\text { Scenario } 4 \\
(50 \% \text { FC trucks })\end{array}$ & 4 & 140 & 144 \\
\hline $\begin{array}{c}\text { Scenario 5 } \\
(100 \% \text { EV })\end{array}$ & 59 & 1174 & 1376 \\
\hline $\begin{array}{c}\text { Scenario 6 } \\
(100 \% \text { FC trucks })\end{array}$ & 63 & 1314 & \\
\hline $\begin{array}{c}\text { 2016 GHG } \\
\text { emission }\end{array}$ & & & \\
\hline
\end{tabular}

As shown in Table 6, a more significant reduction in GHG emissions is possible by converting passenger vehicles from gasoline to renewable electric or hydrogen. However, this is primarily due to the substantial size of the passenger vehicle fleet and the high number of kilometers driven by passenger cars on Highway 401. Using the Canadian carbon price of CAD 40 per tonne of GHG, the monetary value of climate change can be determined. The cost of carbon emissions in 2016 based on this traffic corridor is CAD $55,053,332$. The GHG costs of $100 \%$ green semi-trucks and passenger cars are shown in Table 7.

Table 7. Component costs of GHG emissions produced annually on 401 Toronto under two different traffic profiles.

\begin{tabular}{cccc}
\hline Phase & GHG Cost 2016 & $\begin{array}{c}\text { GHG Cost of 100\% } \\
\text { HFCV Semi-Trucks }\end{array}$ & $\begin{array}{c}\text { GHG Cost of 100\% } \\
\text { Electrified Passenger Cars }\end{array}$ \\
\hline Well-to-Pump & CAD 2,510,946 & CAD 2,353,362 & CAD 157,584 \\
\hline Pump-to-Wheels & CAD 52,542,386 & CAD 46,960,153 & CAD 5,582,233 \\
\hline Well-to-Wheels & CAD 55,053,332 & CAD 49,313,515 & CAD 5,739,817 \\
\hline
\end{tabular}

\subsection{Health Cost}

As shown in Figure 6, traffic-related pollution affects areas in the range of $500 \mathrm{~m}$ from the highway. However, a more substantial effect of traffic-related air pollution can be seen in the range of $200 \mathrm{~m}$ from the highway. An air pollution monitoring station is located close to Highway 401, whose data can be used for model verification. 

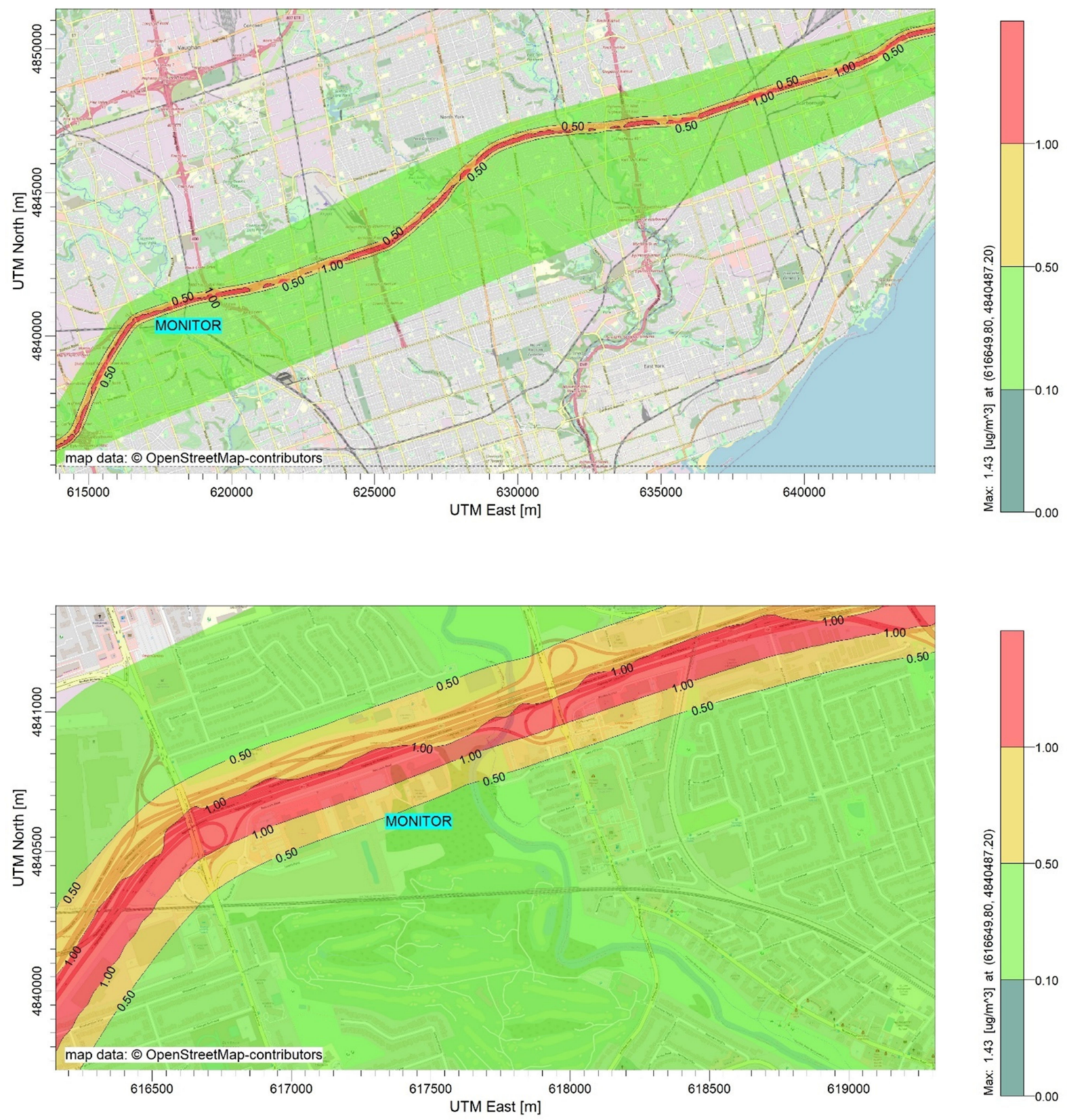

Figure 6. Annual average $\mathrm{PM}_{2.5}$ concentration $\left(\mu \mathrm{g} / \mathrm{m}^{3}\right)$ due to traffic in 2017 along Highway 401 (top) and near the air monitoring site (bottom).

There are four air pollution monitoring stations in Toronto. The only station located in the vicinity of Highway 401 is the Toronto West station. The other three stations are located in areas far from highways. The annual average $\mathrm{PM}_{2.5}$ concentration in Toronto West and Toronto North monitoring station are 7.4 and $7.35 \mu \mathrm{g} / \mathrm{m}^{3}$, respectively. So, the results from monitoring stations do not show a significant difference between Toronto West station and the other three stations in Toronto in terms of $\mathrm{PM}_{2.5}$. The results from the model also show a small $\mathrm{PM}_{2.5}$ concentration due to Highway 401 traffic. However, as one can see in Figure 7, in some hours, the traffic can increase the $\mathrm{PM}_{2.5}$ concentration by more than $4 \mu \mathrm{g} / \mathrm{m}^{3}$. 

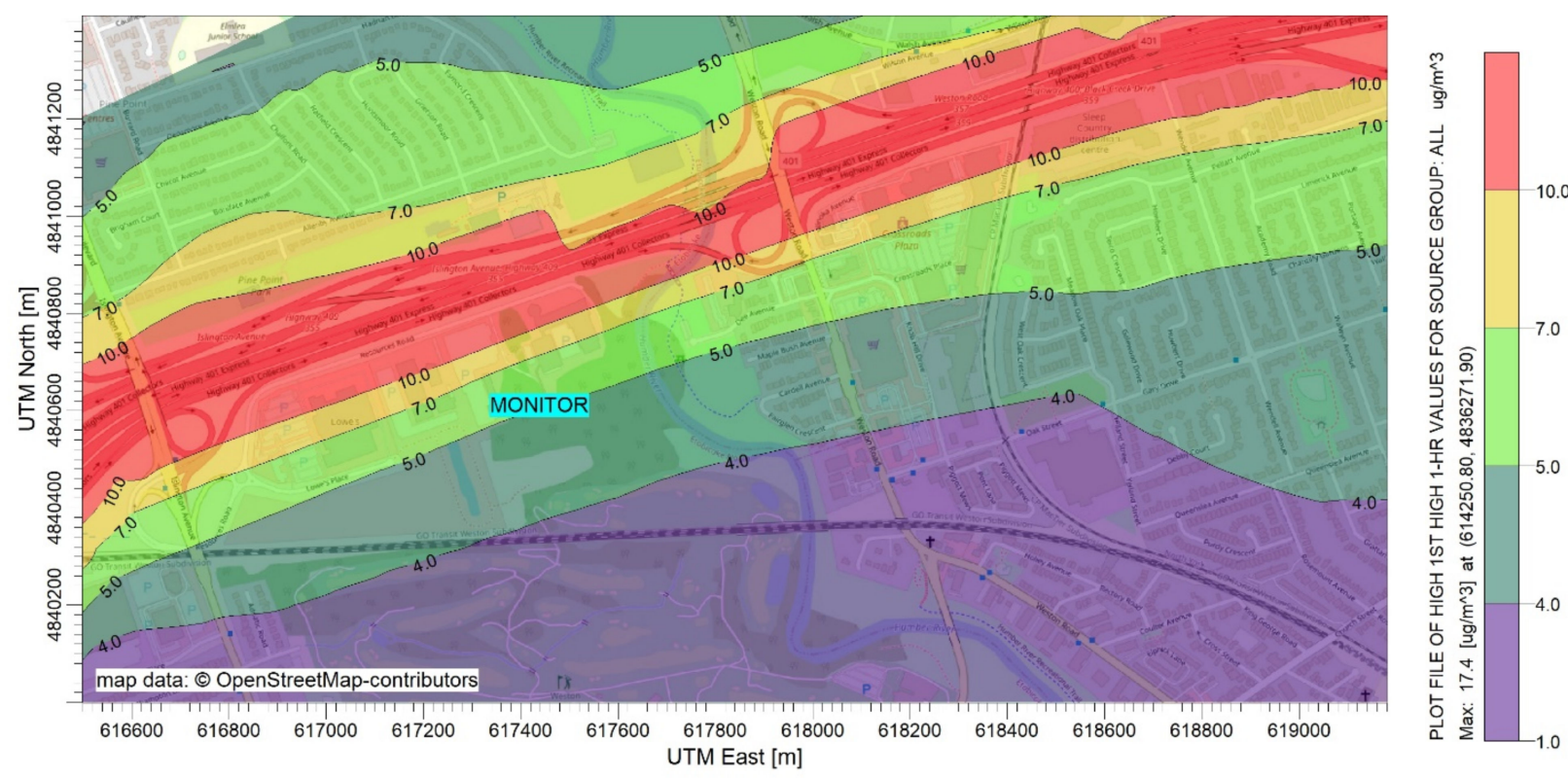

Figure 7. Highest pollution concentration of $\mathrm{PM}_{2.5}$ due to traffic in 2017 in the West Toronto Station $\left(\mu \mathrm{g} / \mathrm{m}^{3}\right)$.

On the other hand, the pollution monitoring data show a significant difference in the average concentration of $\mathrm{NO}_{\mathrm{x}}$. Especially, measurements from Toronto West, the station located near highway 401, show a higher $\mathrm{NO}_{\mathrm{x}}$ concentration. The annual average concentrations of $\mathrm{NO}_{\mathrm{x}}$ in Toronto West and Toronto Downtown stations are 22.66 and $15.69 \mathrm{ppb}$, respectively. $\mathrm{NO}_{2}$ Concentration in Toronto West and Toronto Downtown stations are 14.96 and $12.99 \mathrm{ppb}$, respectively. Comparing these numbers, it can be concluded that a lower share of $\mathrm{NO}_{\mathrm{x}}$ concentration is related to $\mathrm{NO}_{2}$ in the Toronto West station. In other words, a high concentration of $\mathrm{NO}$ is measured in the Toronto West station. The higher share of $\mathrm{NO} / \mathrm{NO}_{\mathrm{x}}$ in Toronto West station is because of proximity to Highway 401. Figure 8 shows the hourly changes in $\mathrm{NO}_{\mathrm{x}}$ concentration in the two stations. It can be concluded that Highway 401 traffic has a higher effect in terms of $\mathrm{NO}_{x}$ rather than $\mathrm{PM}_{2.5}$.

Figures 9 and 10 show the annual average of $\mathrm{NO}_{x}$ concentration due to Highway 401 traffic in 2017. The annual average concentration of $\mathrm{NO}_{\mathrm{x}}$ at the Toronto West station is $7.19 \mu \mathrm{g} / \mathrm{m}^{3}$. To validate the output from AERMOD, it is assumed that the difference between $\mathrm{NO}_{\mathrm{x}}$ annual average concentration in Toronto West station and Toronto Downtown station is due to $\mathrm{NO}_{\mathrm{x}}$ pollution coming out of Highway 401. The annual average concentrations of $\mathrm{NO}_{\mathrm{x}}$ in Toronto West and Toronto Downtown stations are 39.53 and $29.21 \mu \mathrm{g} / \mathrm{m}^{3}$, respectively. The difference between these annual average concentrations, which is assumed to be related to Highway $\mathrm{NO}_{x}$ pollution, is $10.32 \mu \mathrm{g} / \mathrm{m}^{3}$. As the output from AERMOD shows $7.19 \mu \mathrm{g} / \mathrm{m}^{3}$ of $\mathrm{NO}_{\mathrm{x}}$ concentration, the modeling result has a $30.3 \%$ error, which is an acceptable error in air pollution modeling.

Figures 9 and 10 show that at distances further than $2000 \mathrm{~m}$, the annual average $\mathrm{NO}_{\mathrm{x}}$ concentration due to Highway 401 traffic is less than $1 \mu \mathrm{g} / \mathrm{m}^{3}$. In contrast, the average concentration is higher than $5 \mu \mathrm{g} / \mathrm{m}^{3}$ at distances less than $200 \mathrm{~m}$. As shown in Figure 9, the concentration of $\mathrm{NO}_{x}$ is higher in the western parts of Highway 401. The reason is the higher traffic count in those regions. 


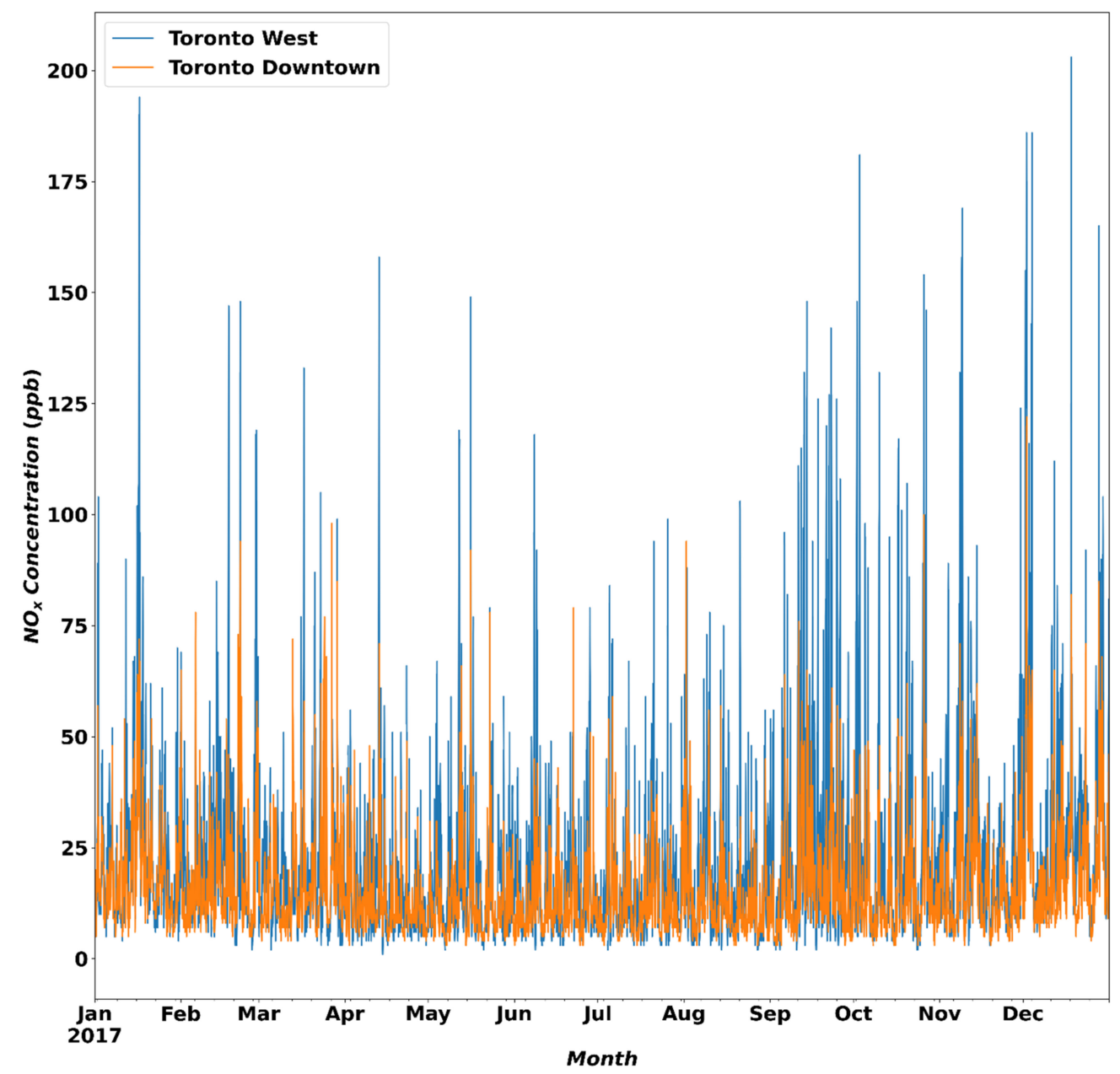

Figure 8. Hourly $\mathrm{NO}_{x}$ concentration in the Toronto West and Toronto Downtown Air Pollution Monitoring Stations in 2017 (ppb).
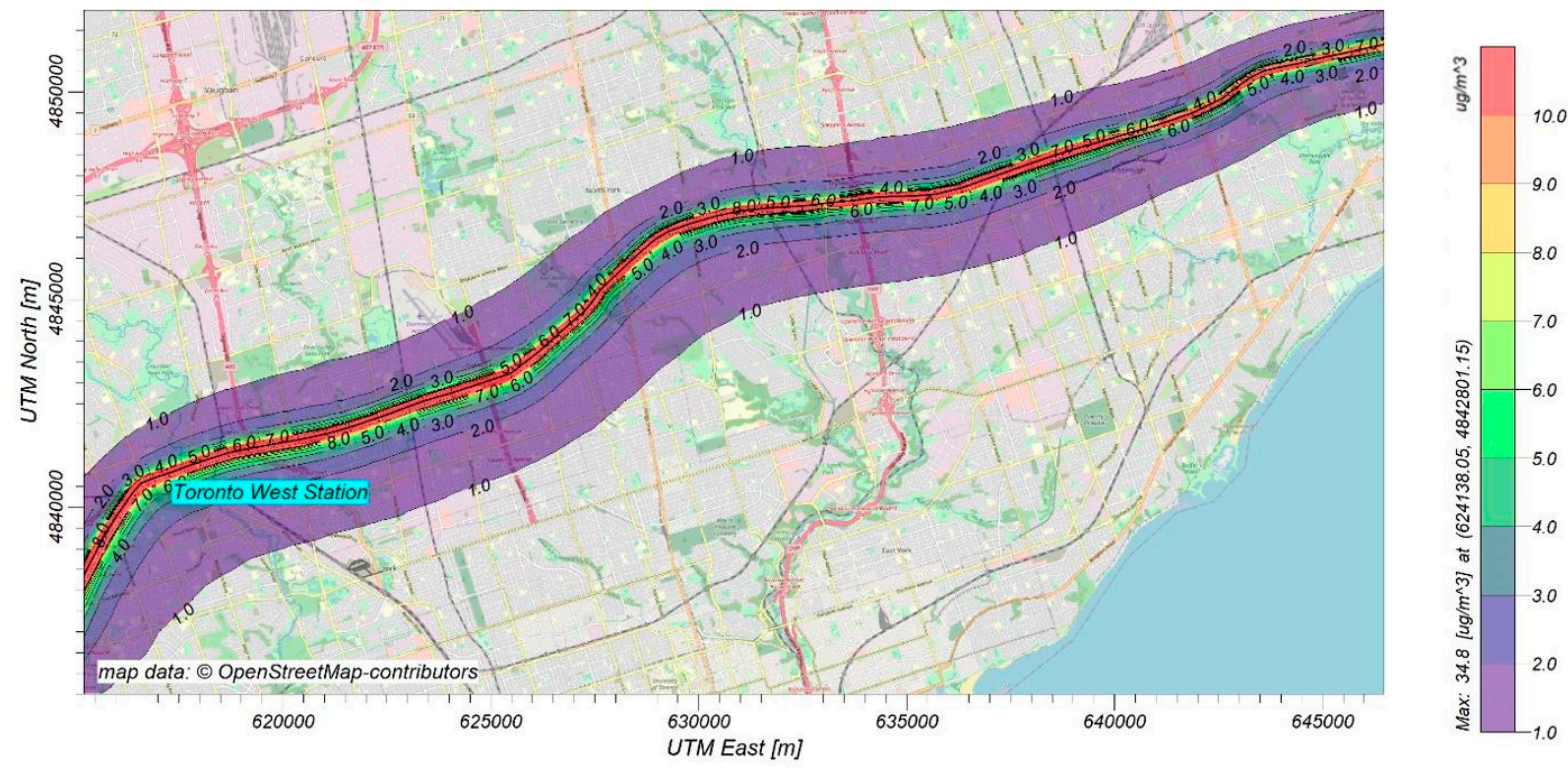

Figure 9. Annual average $\mathrm{NO}_{\mathrm{x}}$ concentration due to traffic in 2017 in the vicinity of Highway $401\left(\mu \mathrm{g} / \mathrm{m}^{3}\right)$. 

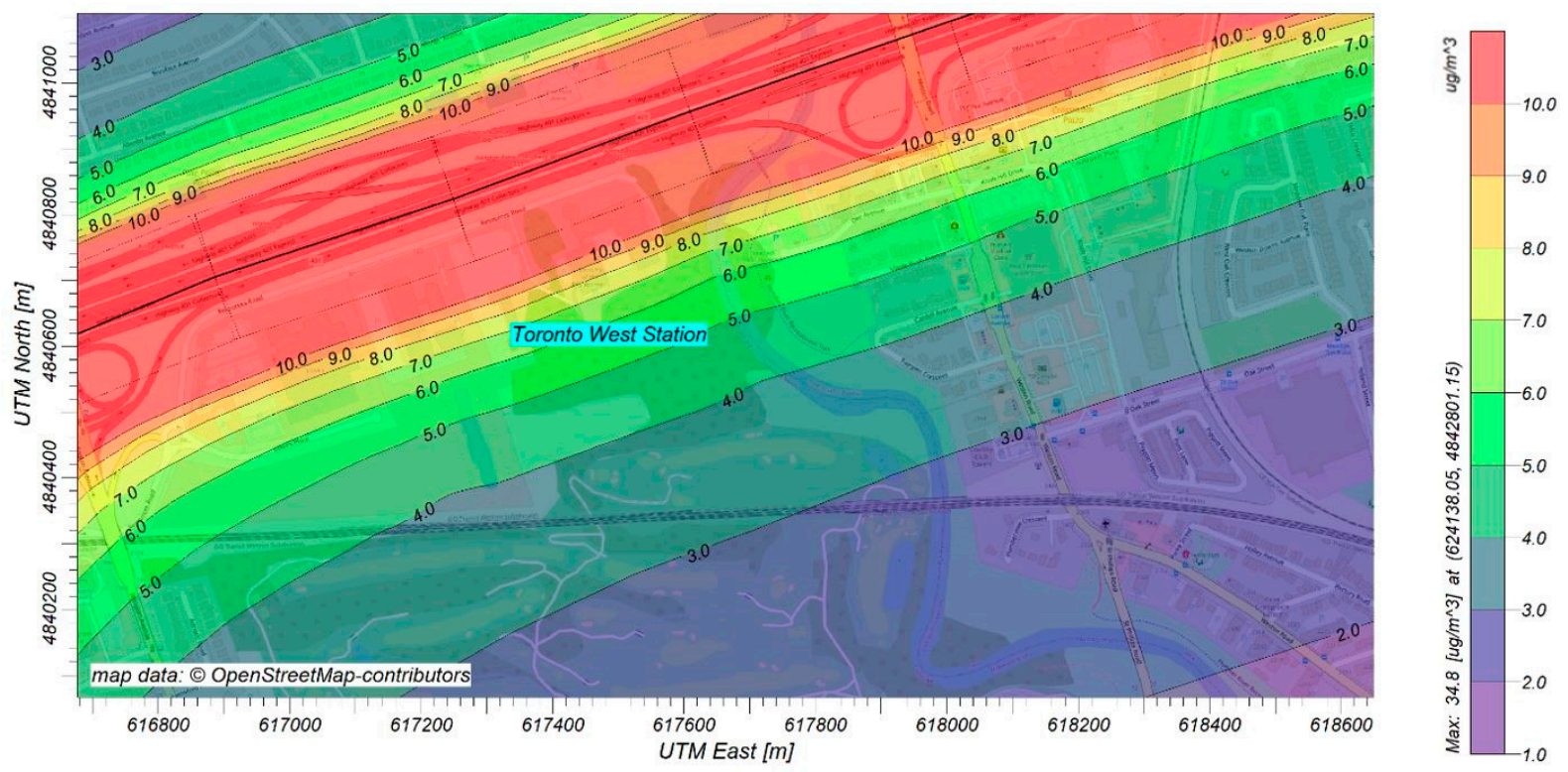

Figure 10. Annual average $\mathrm{NO}_{\mathrm{x}}$ concentration due to traffic in 2017 in vicinity of the West Toronto Air Pollution Monitoring Station $\left(\mu \mathrm{g} / \mathrm{m}^{3}\right)$.

The maximum concentration due to traffic is plotted in Figure 11 and equals $101 \mu \mathrm{g} / \mathrm{m}^{3}$ at the Toronto West station. The annual average and peak concentrations show a significant amount of $\mathrm{NO}_{\mathrm{x}}$, which can cause chronic and acute health problems.
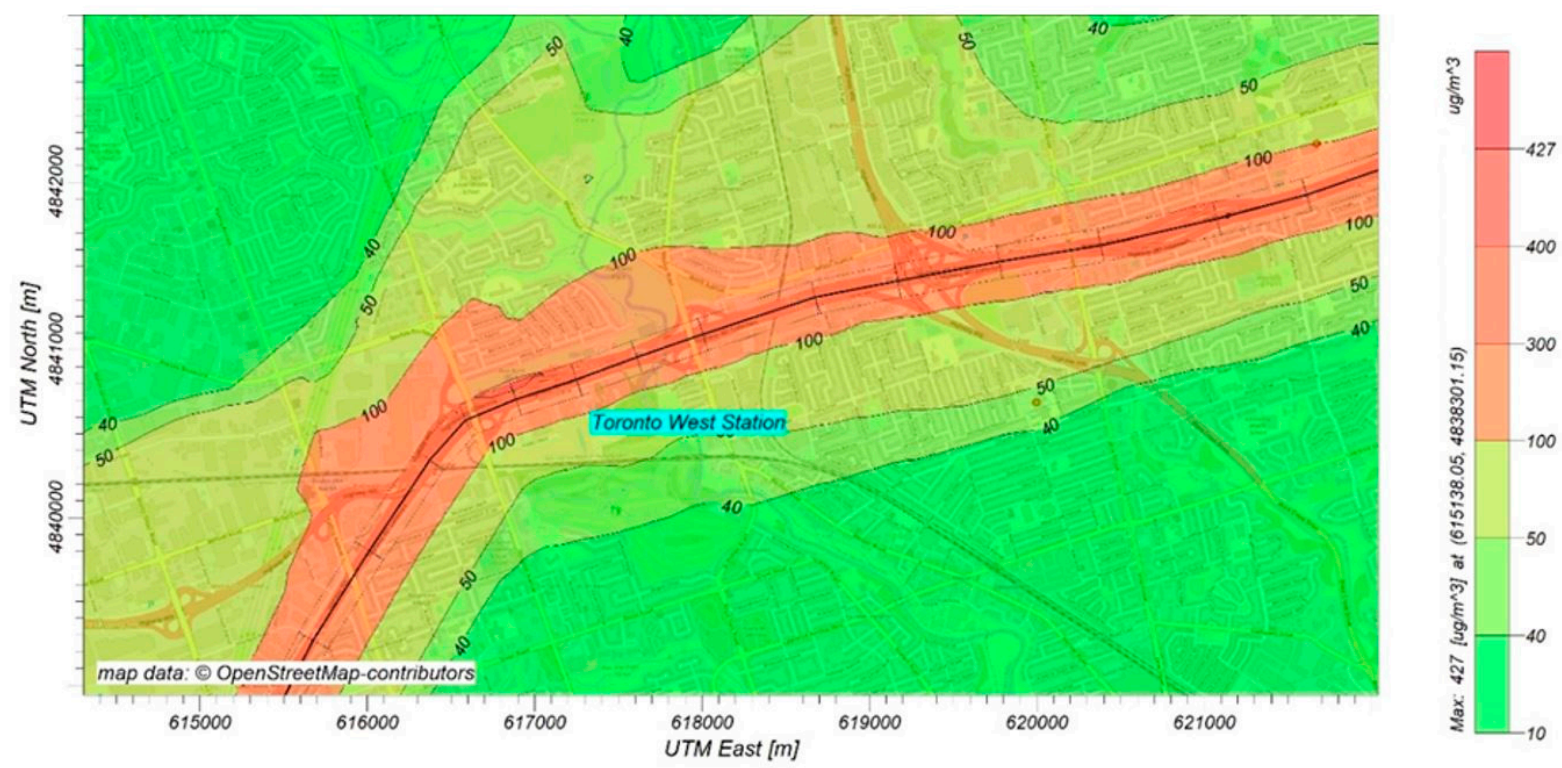

Figure 11. Maximum $\mathrm{NO}_{\mathrm{x}}$ concentration due to traffic in 2017 in vicinity of the West Toronto Air Pollution Monitoring Station $\left(\mu \mathrm{g} / \mathrm{m}^{3}\right)$.

Figure 12 shows the population density in Toronto. It can be seen that although most of the high-populated areas are located in Downtown Toronto, there are some neighborhoods with a high population close to Highway 401. 


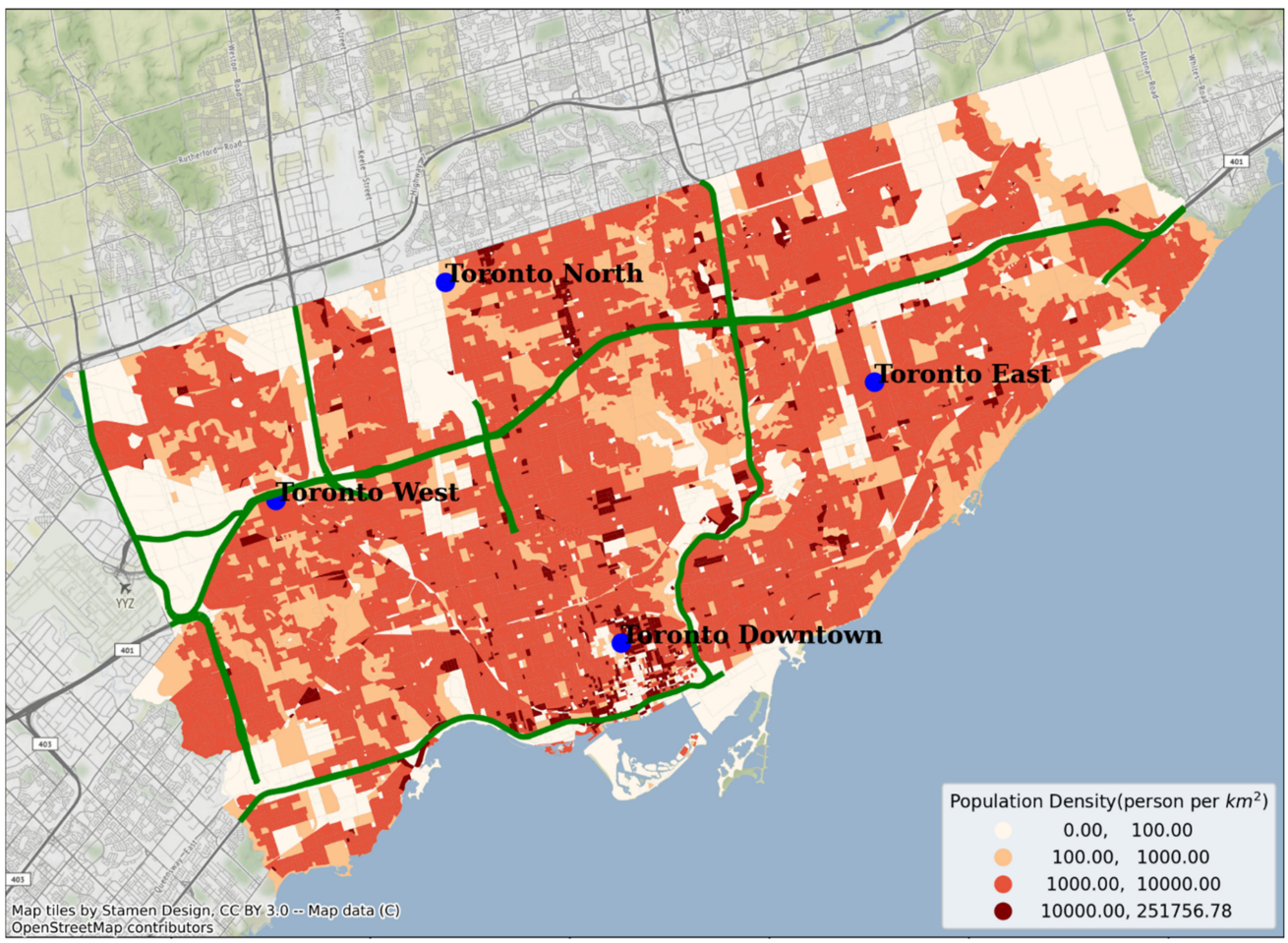

Figure 12. Population density in Toronto in 2016 (person per $\mathrm{km}^{2}$ ).

Combining the results from Figures 9 and 12, one can find the dissemination areas with higher $\mathrm{NO}_{\mathrm{x}}$ concentration due to Highway 401 traffic, shown in Figure 13. Analyzing Figures 12 and 13 together, it can be seen that there are some dissemination areas with low population and high $\mathrm{NO}_{x}$ concentration close to Highway 401, and some dissemination areas with high population and less $\mathrm{NO}_{x}$ concentration far from Highway 401. These two types of dissemination areas are important in terms of health cost calculation. Although the health risk in far regions is lower, the high population increases the number of events. On the other hand, although the population is low near the corridor, the higher concentration increases the health risk.

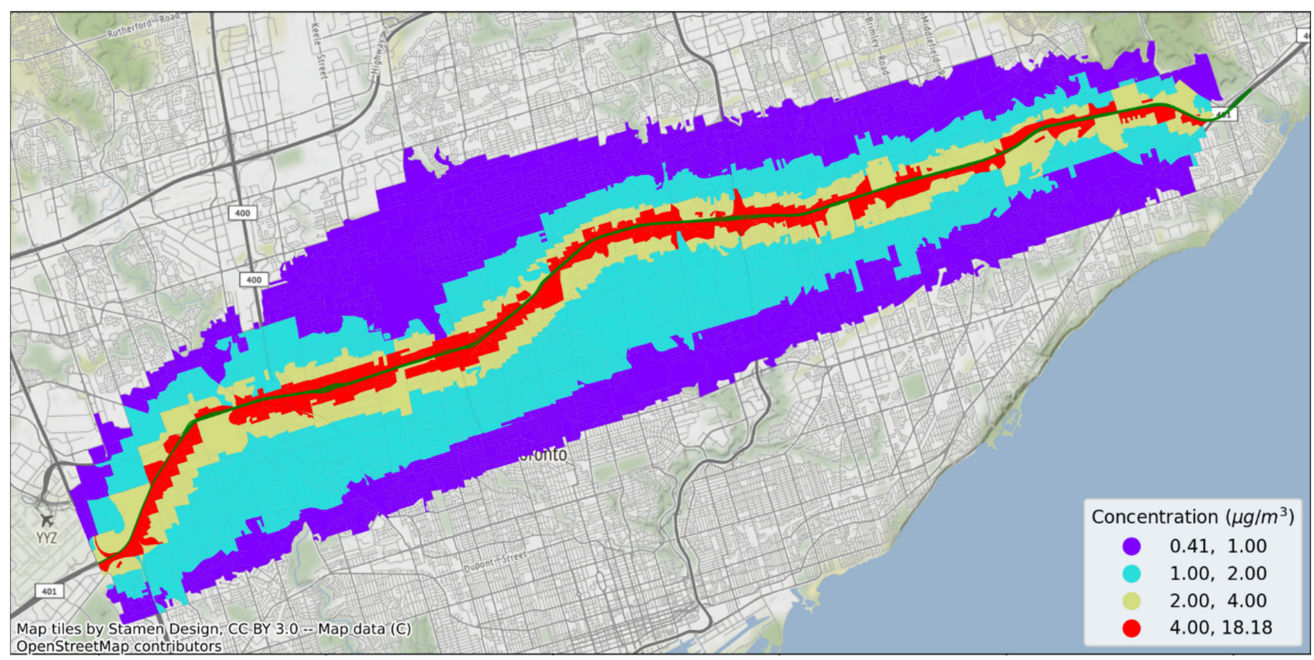

Figure 13. Dissemination areas with higher corridor-related $\mathrm{NO}_{\mathrm{x}}$ concentrations $\left(\mu \mathrm{g} / \mathrm{m}^{3}\right)$.

Combining the population, $\mathrm{NO}_{\mathrm{x}}$ concentration, mortality rate, and increased risk of mortality, Figure 14 can be generated. The total increase in premature deaths due to Highway 401 traffic is 52 (95\% CI 26-78). Using the mean VSL, the total cost of premature deaths 
due to Highway $401 \mathrm{NO}_{\mathrm{x}}$ concentration equals CAD 416 million per year. In comparison to the authors' previous work, in which the health cost of heavy-duty truck pollution along Highway 401 from Windsor to Montreal was estimated, the previous estimation was found to be much lower than the current estimation [5]. In that work, the health cost for all pollutants in all regions around Highway 401 from Windsor to Montreal was found to be around CAD 100 million per year. As stated in that study, estimating the health cost in urban areas using the national health cost average would result in a considerable underestimation. Table 8 shows the premature deaths prevented in different scenarios and the monetary benefits of ZEVs in terms of health cost in each of these scenarios.

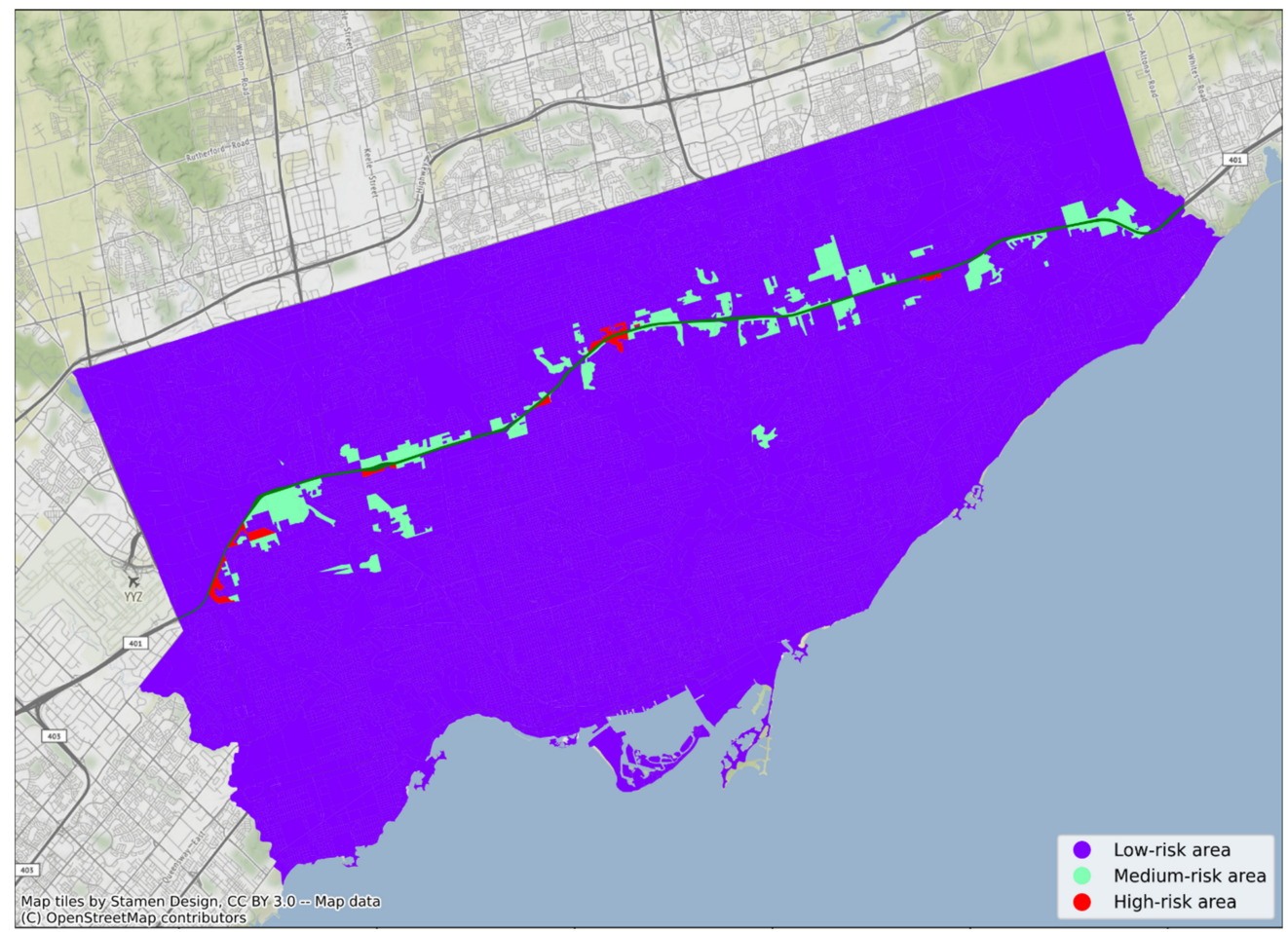

Figure 14. Different health-risk zones in vicinity of Highway 401 due to corridor-related $\mathrm{NO}_{\mathrm{x}}$ pollution.

Table 8. Annual health benefit under different traffic profiles.

\begin{tabular}{ccc}
\hline Scenario & Prevented Death Per Year & $\begin{array}{c}\text { Prevention of Mortality } \\
\text { (CAD Million/Year) }\end{array}$ \\
\hline $\begin{array}{c}\text { Scenario } 1 \\
(10 \% \text { EV })\end{array}$ & $3(95 \%$ CI 2-4) & 24 \\
\hline $\begin{array}{c}\text { Scenario } 2 \\
(10 \% \text { FC Trucks })\end{array}$ & $3(95 \%$ CI 2-4) & 24 \\
\hline $\begin{array}{c}\text { Scenario 3 } \\
(50 \% \text { EV) }\end{array}$ & $12(95 \%$ CI 6-18) & 112 \\
\hline $\begin{array}{c}\text { Scenario } 4 \\
(50 \% \text { FC trucks })\end{array}$ & $14(95 \%$ CI 7-21) \\
\hline $\begin{array}{c}\text { Scenario 5 } \\
(100 \% \text { EV) }\end{array}$ & $24(95 \%$ CI 12-36) \\
\hline $\begin{array}{c}\text { Scenario 6 } \\
(100 \% \text { FC trucks })\end{array}$ & $28(95 \%$ CI 14-42) \\
\hline
\end{tabular}

Figure 15 shows the comparison of the $\mathrm{NO}_{\mathrm{x}}$ concentration between the all 6 scenarios. As can be seen, the annual average of highway traffic-related $\mathrm{NO}_{\mathrm{x}}$ pollution decreases by 
more than 50\% in Scenario 6, in which all heavy-duty trucks become FC trucks. In other words, although heavy-duty trucks have less than $10 \%$ of the traffic count share, they are responsible for more than $50 \%$ of Highway $401 \mathrm{NO}_{\mathrm{x}}$ pollution.
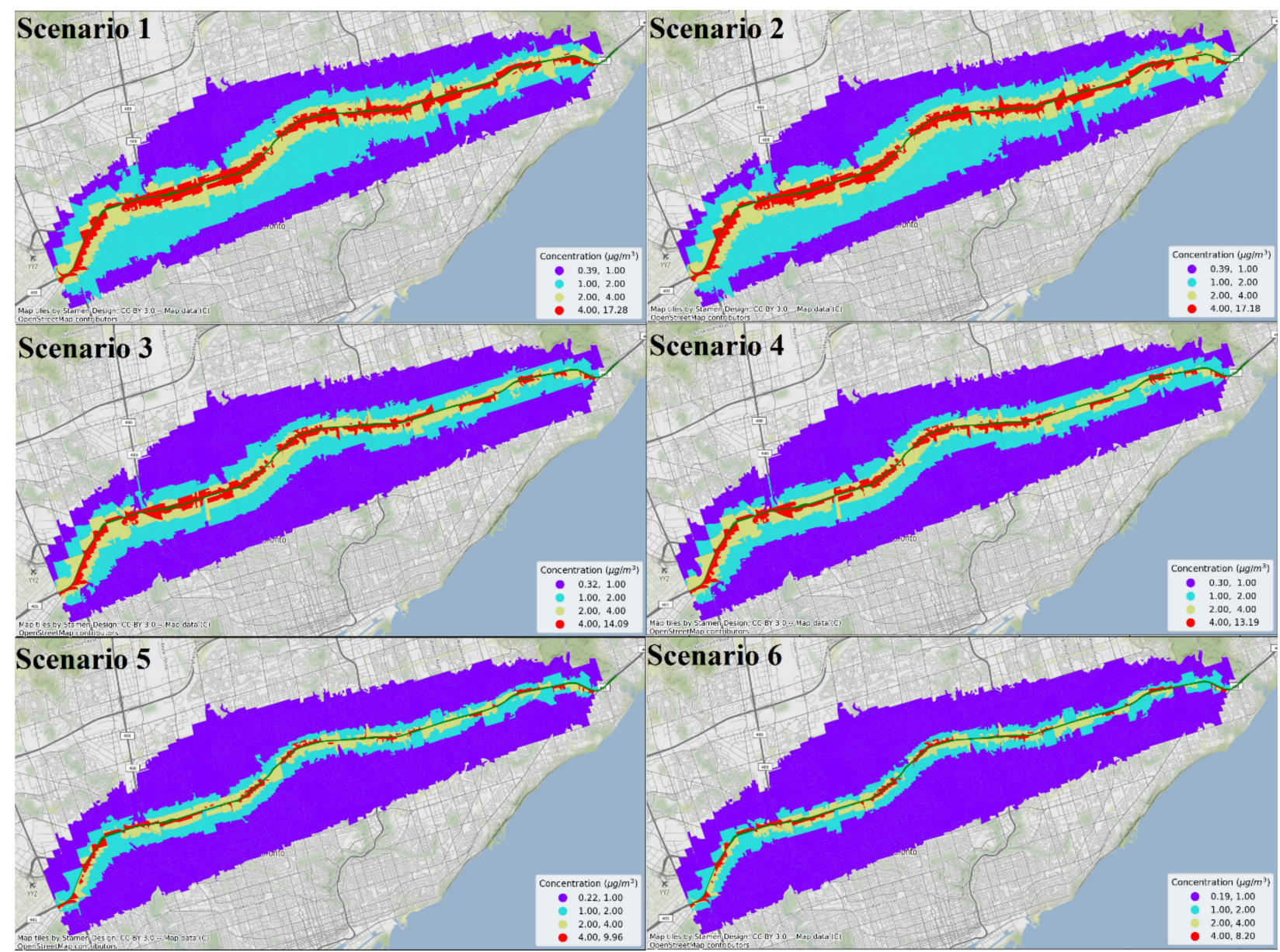

Figure 15. Annual average corridor-related $\mathrm{NO}_{x}$ concentrations in all scenarios $\left(\mu \mathrm{g} / \mathrm{m}^{3}\right)$.

Comparing the results from Tables 7 and 8, one can see that the health cost of traffic for Highway 401 is much higher than the environmental cost. For instance, the health and environmental benefit of Scenario 6 (100\% FC trucks) are CAD 224 million and CAD 5.7 million per year, respectively. In total, Scenarios 5 and 6 have the benefit of around CAD 241 million and CAD 230 million per year, respectively.

The results also show that despite a lower share of heavy-duty trucks in Highway 401 traffic, they have almost the same significance as passenger vehicles regarding total environmental and health costs. In other words, although reaching $100 \%$ FC trucks scenario is more accessible than achieving $100 \%$ electric passenger vehicles in terms of effort and money, 100\% FC trucks scenario has almost the same benefit as 100\% electric passenger vehicles.

\section{Conclusions}

The transportation sector has the highest potential for environmental and health cost reduction amongst other energy-related sectors such as the commercial, industrial, and residential sectors. Specifically, pollutants such as $\mathrm{PM}, \mathrm{O}_{3}, \mathrm{SO}_{\mathrm{x}}$, and $\mathrm{NO}_{\mathrm{x}}$ emitted from major highways significantly impact people's life expectancy. Also, these hightraffic highways have a major role in producing GHG emissions. Substitution of passenger vehicles and heavy-duty trucks with ZEVs can reduce the negative impact of transportation on GHG emissions and health costs. 
This paper presented a model to investigate the environmental and health costs related to Highway 401, which is the busiest highway in Canada. An integrated model was built to calculate the health benefit of the substitution of fossil-fuel vehicles with ZEVs. A combination of MOVES2014b, WRF model, and AERMOD were used to calculate the concentrations of $\mathrm{PM}_{2.5}$ and $\mathrm{NO}_{\mathrm{x}}$ in the vicinity of Highway 401. Then, the mortality risk of $\mathrm{NO}_{\mathrm{x}}$ was calculated using hazard ratios from the literature. The health cost of $\mathrm{NO}_{\mathrm{x}}$ in six scenarios was calculated using VSL. Also, GREET was used to assess life cycle $\mathrm{CO}_{2}$ emission from heavy-duty trucks and passenger vehicles in six different scenarios. Then, the environmental cost was calculated by multiplying the total $\mathrm{CO}_{2}$ emission in different scenarios by the Canadian carbon tax, which is CAD 40 per tonne of $\mathrm{CO}_{2}$.

The results show that $\mathrm{NO}_{\mathrm{x}}$ has the highest impact on the mortality rate. Other pollutants are less likely to have high impacts on human health because of their lower concentration or lower hazard risk. Also, the health impact due to trucks pollution is higher than passenger vehicles, despite their lower traffic share. It can be concluded that investing in trucks pollution reduction is more rational. Also, the environmental cost of Highway 401 traffic is calculated to be CAD 55 million per year, which can be reduced to less than CAD 6 million per year by converting passenger vehicles to zero-emission electric vehicles. Also, by converting all trucks to FC trucks, the environmental cost can be reduced to CAD 49 million per year. Finally, it was concluded that investing in FC trucks has a higher priority than investing in electric passenger vehicles. Despite a lower share in Highway 401 traffic, the economic benefit of the $100 \%$ FC truck scenario is almost the same as the $100 \%$ electric passenger vehicle scenario.

Author Contributions: Conceptualization, H.S. and M.F.; methodology, H.S., M.M. and S.W.; software, M.M., S.W. and J.T.; validation, M.-K.T., S.W. and K.R.; formal analysis, H.S. and M.M.; investigation, M.-K.T.; resources, J.T. and M.F.; data curation, H.S. and Y.L.; writing—original draft preparation, H.S., M.-K.T., Y.L. and S.W.; writing-review and editing, M.M., J.T., K.R. and M.F.; visualization, H.S., M.M. and Y.L.; supervision, J.T., K.R. and M.F.; project administration, M.F.; funding acquisition, K.R. and M.F. All authors have read and agreed to the published version of the manuscript.

Funding: This research was funded by: University of Waterloo; Canada Research Chair Tier I-ZeroEmissions Vehicles and Hydrogen Energy Systems, Grant number: 950-232215; and the Natural Sciences and Engineering Research Council of Canada (NSERC), Discovery Grants Program, RGPIN2020-04149.

Data Availability Statement: The data presented in this study are available on request from the corresponding author. The data are not publicly available due to confidentiality.

Acknowledgments: This work was supported by equipment and manpower from the University of Waterloo. Special thanks to Danielle Skeba for their contribution in editing the paper.

Conflicts of Interest: The authors declare no conflict of interest.

\section{References}

1. Shamsi, H.; Haghi, E.; Raahemifar, K.; Fowler, M. Five-year technology selection optimization to achieve specific $\mathrm{CO}_{2}$ emission reduction targets. Int. J. Hydrogen Energy 2019, 44, 3966-3984. [CrossRef]

2. Haghi, E.; Shamsi, H.; Dimitrov, S.; Fowler, M.; Raahemifar, K. Assessing the potential of fuel cell-powered and battery-powered forklifts for reducing GHG emissions using clean surplus power; a game theory approach. Int. J. Hydrog. Energy 2020, 45, 34532-34544. [CrossRef]

3. Tran, M.-K.; Akinsanya, M.; Panchal, S.; Fraser, R.; Fowler, M. Design of a Hybrid Electric Vehicle Powertrain for Performance Optimization Considering Various Powertrain Components and Configurations. Vehicles 2021, 3, 2. [CrossRef]

4. Tran, M.-K.; Sherman, S.; Samadani, E.; Vrolyk, R.; Wong, D.; Lowery, M.; Fowler, M. Environmental and Economic Benefits of a Battery Electric Vehicle Powertrain with a Zinc-Air Range Extender in the Transition to Electric Vehicles. Vehicles 2020,2 , 21. [CrossRef]

5. Shamsi, H.; Tran, M.-K.; Akbarpour, S.; Maroufmashat, A.; Fowler, M. Macro-Level Optimization of Hydrogen Infrastructure and Supply Chain for Zero-emission Vehicles on a Canadian Corridor. J. Clean. Prod. 2020, 125163. [CrossRef]

6. Tran, M.-K.; Bhatti, A.; Vrolyk, R.; Wong, D.; Panchal, S.; Fowler, M.; Fraser, R. A Review of Range Extenders in Battery Electric Vehicles: Current Progress and Future Perspectives. World Electr. Veh. J. 2021, 12, 54. [CrossRef] 
7. Brugge, D.; Durant, J.L.; Rioux, C. Near-highway pollutants in motor vehicle exhaust: A review of epidemiologic evidence of cardiac and pulmonary health risks. Environ. Health 2007, 6. [CrossRef] [PubMed]

8. Gasana, J.; Dillikar, D.; Mendy, A.; Forno, E.; Ramos Vieira, E. Motor vehicle air pollution and asthma in children: A meta-analysis. Environ. Res. 2012, 117, 36-45. [CrossRef]

9. Aldhafeeri, T.; Tran, M.-K.; Vrolyk, R.; Pope, M.; Fowler, M. A Review of Methane Gas Detection Sensors: Recent Developments and Future Perspectives. Inventions 2020, 5, 28. [CrossRef]

10. Cohen, A.J.; Ross Anderson, H.; Ostro, B.; Pandey, K.D.; Krzyzanowski, M.; Künzli, N.; Smith, K. The Global Burden of Disease Due to Outdoor Air Pollution. J. Toxicol. Environ. Health Part A 2005, 68, 1301-1307. [CrossRef] [PubMed]

11. Jerrett, M.; Finkelstein, M.M.; Brook, J.R.; Arain, M.A.; Kanaroglou, P.; Stieb, D.M.; Sears, M.R. A Cohort Study of Traffic-Related Air Pollution and Mortality in Toronto, Ontario, Canada. Environ. Health Perspect. 2009, 117, 772-777. [CrossRef]

12. Burnett, R.T.; Cakmak, S.; Brook, J.R. The Effect of the Urban Ambient Air Pollution Mix on Daily Mortality Rates in 11 Canadian Cities. Can. J. Public Health 1998, 89, 152-156. [CrossRef]

13. Brook, J.; Burnett, R.; Dann, T. Further interpretation of the acute effect of nitrogen dioxide observed in Canadian time-series studies. J. Expo. Sci. Environ. Epidemiol. 2007, 17, S36-S44. [CrossRef] [PubMed]

14. Bai, L.; Shin, S.; Burnett, R.T.; Kwong, J.C.; Hystad, P.; van Donkelaar, A.; Chen, H. Exposure to ambient air pollution and the incidence of congestive heart failure and acute myocardial infarction: A population-based study of 5.1 million Canadian adults living in Ontario. Environ. Int. 2019, 132, 105004. [CrossRef]

15. Grennfelt, P.; Engleryd, A.; Forsius, M. Acid rain and air pollution: 50 years of progress in environmental science and policy. Ambio 2020, 49, 849-864. [CrossRef]

16. Pinault, L.; Crouse, D.; Jerrett, M.; Brauer, M.; Tjepkema, M. Spatial associations between socioeconomic groups and $\mathrm{NO}_{2}$ air pollution exposure within three large Canadian cities. Environ. Res. 2016, 147, 373-382. [CrossRef]

17. Touchaei, A.G.; Akbari, H.; Tessum, C.W. Effect of increasing urban albedo on meteorology and air quality of Montreal (Canada)Episodic simulation of heat wave in 2005. Atmos. Environ. 2016, 132, 188-206. [CrossRef]

18. Adams, M.D. Air pollution in Ontario, Canada during the COVID-19 State of Emergency. Sci. Total. Environ. 2020, 140516. [CrossRef]

19. McCubbin, D.R.; Delucchi, M.A. The Health Costs of Motor-Vehicle-Related Air Pollution. J. Transp. Econ. Policy 1999, 33, 253-286.

20. Muller, N.Z.; Mendelsohn, R. Measuring the damages of air pollution in the United States. J. Environ. Econ. Manag. 2007, 54, 1-14. [CrossRef]

21. Martinez, G.; Spadaro, J.; Chapizanis, D.; Kendrovski, V.; Kochubovski, M.; Mudu, P. Health Impacts and Economic Costs of Air Pollution in the Metropolitan Area of Skopje. Int. J. Environ. Res. Public Health 2018, 15, 626. [CrossRef] [PubMed]

22. Xia, Y.; Guan, D.; Jiang, X.; Peng, L.; Schroeder, H.; Zhang, Q. Assessment of socioeconomic costs to China's air pollution. Atmos. Environ. 2016, 139, 147-156. [CrossRef]

23. Lu, X.; Yao, T.; Fung, J.C.H.; Lin, C. Estimation of health and economic costs of air pollution over the Pearl River Delta region in China. Sci. Total. Environ. 2016, 566-567, 134-143. [CrossRef]

24. Giannadaki, D.; Giannakis, E.; Pozzer, A.; Lelieveld, J. Estimating health and economic benefits of reductions in air pollution from agriculture. Sci. Total. Environ. 2018, 622-623, 1304-1316. [CrossRef] [PubMed]

25. Nowak, D.J.; Hirabayashi, S.; Doyle, M.; McGovern, M.; Pasher, J. Air pollution removal by urban forests in Canada and its effect on air quality and human health. Urban For. Urban Green. 2018, 29, 40-48. [CrossRef]

26. Minet, L.; Chowdhury, T.; Wang, A.; Gai, Y.; Posen, D.; Roorda, M.; Hatzopoulou, M. Quantifying the air quality and health benefits of greening freight movements. Environ. Res. 2020, 109193. [CrossRef]

27. Fiscal Monitor, October 2019: How to Mitigate Climate Change. Available online: https://www.imf.org/en/Publications/FM/ Issues / 2019/09/12/ fiscal-monitor-october-2019 (accessed on 9 January 2021).

28. Carbon Pricing Dashboard: Map Data. Available online: https://carbonpricingdashboard.worldbank.org/map_data (accessed on 9 January 2021).

29. Motor Vehicle Emission Simulator (MOVES). Available online: https:/ /www.epa.gov / moves (accessed on 26 November 2020).

30. Ministry of Transportation Technical Publications: Traffic Volumes. Available online: https://www.library.mto.gov.on.ca/ SydneyPLUS/TechPubs/Portal/tp/tvSplash.aspx (accessed on 9 January 2021).

31. Air Quality Dispersion Modeling-Preferred and Recommended Models: AERMOD Modeling System. Available online: https: //www.epa.gov/scram/air-quality-dispersion-modeling-preferred-and-recommended-models (accessed on 26 November 2020).

32. Powers, J.G.; Klemp, J.B.; Skamarock, W.C.; Davis, C.A.; Dudhia, J.; Gill, D.O.; Coen, J.L.; Gochis, D.J.; Ahmadov, R.; Peckham, S.E.; et al. The Weather Research and Forecasting Model: Overview, System Efforts, and Future Directions. Bull. Am. Meteorol. Soc. 2017, 98, 1717-1737. [CrossRef]

33. Faustini, A.; Rapp, R.; Forastiere, F. Nitrogen dioxide and mortality: Review and meta-analysis of long-term studies. Eur. Respir. J. 2014, 44, 744-753. [CrossRef] [PubMed]

34. Mortality Rates, by Age Group. Available online: https:/ / www150.statcan.gc.ca/t1/tbl1/en/tv.action?pid=1310071001 (accessed on 9 January 2021).

35. The Value of a Statistical Life: Economics and Politics. Available online: https://strata.org/pdf/2017/vsl-full-report.pdf (accessed on 9 January 2021). 
36. Zhang, A.; Boardman, A.E.; Gillen, D.; Waters, I.I.W.G. Towards Estimating the Social and Environmental Costs of Transportation in Canada. Report for Transport Canada. Available online: http://www.bv.transports.gouv.qc.ca/mono/0965490.pdf (accessed on 25 July 2021).

37. Cunanan, C.; Tran, M.-K.; Lee, Y.; Kwok, S.; Leung, V.; Fowler, M. A Review of Heavy-Duty Vehicle Powertrain Technologies: Diesel Engine Vehicles, Battery Electric Vehicles, and Hydrogen Fuel Cell Electric Vehicles. Clean Technol. 2021, 3, 28. [CrossRef] 